\title{
Synoptic climatology of winter intense precipitation events along the Mediterranean coasts
}

\author{
M. Reale ${ }^{1, *}$ and P. Lionello ${ }^{1,2}$ \\ ${ }^{1}$ Department of Material Sciences, University of Salento, Lecce, Italy \\ ${ }^{2}$ Centro Euro-Mediterraneo sui Cambiamenti Climatici (CMCC), Lecce, Italy \\ *now at: University of Trieste, Department of Mathematics and Informatics, Trieste, Italy
}

Correspondence to: M. Reale (mcreal82@ hotmail.com)

Received: 6 September 2012 - Published in Nat. Hazards Earth Syst. Sci. Discuss.: Revised: 31 December 2012 - Accepted: 30 April 2013 - Published: 4 July 2013

\begin{abstract}
The link between winter (December-JanuaryFebruary) precipitation events at 15 Mediterranean coastal locations and synoptic features (cyclones and Northern Hemisphere teleconnection patterns) is analyzed. A list of precipitation events has been produced; $q$ percentile thresholds $\left(\mathrm{Th}_{q}\right.$ ) and corresponding frequency $\mathrm{N}_{q}$ (for $q$ equal to 25, 50, 90 and 98) have been considered. A negative trend has been detected in total precipitation and $\mathrm{N}_{50}$ at many locations, while no significant trend in $\mathrm{N}_{25}, \mathrm{~N}_{90}$ and $\mathrm{N}_{98}$ has been found. The negative phase of the North Atlantic Oscillation (NAO) and the East Atlantic/West Russia pattern (EAWR) compete for exerting the largest influence on the frequency of the 25th, 50th and 90th percentiles, with EAWR and NAO exerting their largest influence in the central and western Mediterranean areas, respectively. All percentiles show a similar behavior except for the 98th percentile, which shows no convincing link to any teleconnection pattern. The cyclone tracks that are associated with precipitation events have been selected using the ERA-40 reanalysis data, and a strong link between intense precipitation and cyclones is shown for all stations. In general, the probability of detecting a cyclone within a distance of $20^{\circ}$ from each station increases with the intensity of the precipitation event and decreases with the duration of a dry period. The origin and track of cyclones producing intense precipitation differ among different areas. When precipitation occurs in the northwestern Mediterranean, cyclones are generally either of Atlantic origin or secondary cyclones associated with the passage of major cyclones north of the Mediterranean Basin, while they are mostly generated inside the region itself for events at the eastern Mediterranean coast. An important fraction of
\end{abstract}

intense events in the southern areas is produced by cyclones that are generated over northern Africa. The analysis of sea level pressure and geopotential height at $500 \mathrm{hPa}$ highlights the important role of cyclone depth, circulation strength, surrounding synoptic condition, and of slow speed of the cyclone center for producing intense precipitation events.

\section{Introduction}

The Mediterranean region (MR, Fig. 1) usually includes the continental areas surrounding the Mediterranean Sea, southern Europe , northern Africa and the Middle East (e.g., Lionello et al., 2006a; Mehta and Yang, 2008). The region is characterized by a highly complex land-sea distribution, which affects the atmospheric circulation over it, and by the presence of the Mediterranean sea, which acts as source of moisture and energy for the development of cyclones ( $\mathrm{Li}-$ onello et al., 2006b; Ulbrich et al., 2012).

Because of the morphology of the territory, with highly populated, industrialized and touristic areas, the MR is particularly sensitive to the impact of heavy rain and flooding (MEDEX, Jansa et al., 2001a). A report (based on $10 \mathrm{yr}$ of data) prepared by the Munich Reinsurance Company collects 166 cases of heavy rainfall and floods with over 1900 deaths and over $6000 \mathrm{M}$ Euro economic losses (Lionello et al., 2006b). The Programme of Natural Hazards of the Spanish Directorate of Civil Defence reported 155 deaths by heavy rain and flood events (Jansa et al., 2001a). According to the Hellenic Agricultural Insurance Organization (ELGA), for the year 2002 alone, the economic losses due to heavy 
precipitation and floods were about $180 \mathrm{M}$ Euro. Single disastrous events have been recorded, such as the storm of 4 November 1966 (De Zolt et al., 2006), which hit central and northeastern Italy and caused more than 50 deaths and huge damages in the eastern Alps, Florence and Venice. More examples can be found in the MEDEX list of selected cases (Jansà et al., 2001a).

The analysis of winter precipitation in the MR has been object of several recent studies (such as Alpert et al., 2002; Zhang et al., 2005; Norrant and Douguèdroit, 2006; Toreti et al., 2010; Reiser and Kutiel, 2012). The wet/dry connotation, which characterized the so-called Mediterranean climate, is not valid for the whole region and precipitation in the MR presents a high spatial and temporal variability of rainfall regimes (Lionello et al., 2006a). Reiser and Kutiel (2010) identified two main regions in the MR. The first region, corresponding approximately to the northern Mediterranean, where precipitation occurs throughout the year, includes four stations considered in this study: Barcelona, Marseille, Genova and Rijeka. The second region, corresponding approximately to the southern Mediterranean and characterized by a long dry period occurring during the warm season and precipitation occurring during the cold season, includes all other stations considered in this study. Precipitation patterns are correlated to midlatitude teleconnections (Trigo et al., 2006) such as the North Atlantic Oscillation (NAO), East Atlantic/West Russia (EAWR) and Scandinavian (SCA) patterns, and linked to other global patterns such as El Nino/Southern Oscillation (ENSO), Asian and African monsoons (Alpert et al., 2006).

Large variability of precipitation at regional scale prevents detection of a significant general tendency in total precipitation during the second half of the 20th century; however, considering all studies, the majority of indications suggest a negative trend. Results are controversial for extreme precipitation. For example, a significant decrease in the winter sum of daily precipitation above $10 \mathrm{~mm}$ has been observed in the Italian, Greek and eastern Mediterranean subregions by Norrant and Douguèdroit (2006). Toreti et al. (2010), analyzing 20 daily precipitation time series at coastal sites in the MR, found significant negative trends in eight stations for total precipitation (located in France, Italy, Greece and Cyprus) and in six stations for extreme precipitation. Alpert et al. (2002), taking into account six precipitation categories from light (daily amount between 0 and $4 \mathrm{~mm}$ ) to torrential (daily amount greater than $128 \mathrm{~mm}$ ), have observed an increasing trend for higher categories and a decreasing one for the central categories in Spain and Italy, but no significant trend in Israel and Cyprus. No significant trend in extreme events in the Middle East has been found by Zhang et al. (2005), nor by Moberg et al. (2006) in the western Mediterranean.

Mediterranean cyclones represent a well-distinct element of global climate. The basin is crossed by a storm track with most areas of cyclogenesis in the western basin and of cy- clolysis in central and eastern areas (Wallace et al., 1988; Hoskins and Hodges, 2002). In the MR, cyclones play an important role in precipitation and its extremes especially in winter (Trigo et al., 2000; Jansa et al., 2001b; Maheras and Anagnostopoulou, 2002; Maheras et al., 2004). For instance, in Greece about $92 \%$ of rainfall during the rainy period (October-March) is produced by cyclones (Maheras and Anagnostopoulou, 2002). The analysis of the frequency of cyclones and the probability of precipitation during winter for the period 1958-2000 has shown that the decreasing trends in the number of wet days and the probability of rainfall are consistent with the observed changes in frequency of the various types of cyclones (Maheras et al., 2004). The association between cyclones and precipitation has been used for explaining the decrease of precipitation in future climate scenarios (Lionello and Giorgi, 2007).

Intense precipitation events can be produced and sustained by cyclones through their capability to organize a warm and wet feeding flow. Deep and continued convection may occur even when the flow is not particularly strong, especially if moist air is advected above mountain barriers (Jansa et al., 2000). For most cases (around $90 \%$ ) of heavy precipitation in the western Mediterranean, it has been established that there was a cyclone in the vicinity (Jansa et al., 2001b), to which - even if it was small, weak and shallow - a significant role in triggering and/or sustaining rain has been attributed (Jansa et al., 2000). The relevance of cyclonic features was further confirmed by Funatsu et al. (2009), who found an upper-level trough to the west of the area where precipitation occurs, which is, in general, deeper for extreme rainfall. Toreti et al. (2010) have investigated the relationship between extreme precipitations and the large-scale atmospheric circulation in the upper, mid and low troposphere and have identified different patterns of SLP and geopotential height at $500 \mathrm{hPa}$ for the western and eastern Mediterranean (WM and EM) that favor a flow of moisture in the midtroposphere from the Atlantic to the WM and from the Mediterranean to the EM, respectively.

The goals of this study are the following: (i) to characterize the relation of precipitation events with large-scale circulation patterns (teleconnections), (ii) to confirm the association of precipitation with cyclones by extending to the whole MR the results of Jansa et al. (2001b), (iii) to describe the differences of tracks and cyclogenesis areas among cyclones producing rain in different areas of the MR and (iv) to identify the characteristics of cyclones that are responsible for severe precipitation events.

Section 2 describes the data and methodology used. The analysis, which considered the period 1958-2001, has been based on daily precipitation time series contained in the ECA (European Climate Assessment, Haylock et al., 2008) dataset and cyclone tracks produced by applying a cyclone tracking algorithm (Lionello et al., 2002) to the ERA40 (ECMWF-Re-Analysis) SLP (Sea Level Pressure) fields (Gibson et al., 1996). Section 3 describes the characteristics 
of precipitation events and of cyclones producing severe precipitation (tracks, location of cyclogenesis and cyclolysis, location at the peak of the intense precipitation event, moisture distribution in the middle troposphere, extension, depth and other parameters). It also discusses the link between precipitation events and large-scale teleconnection patterns. Section 4 compares the characteristics of cyclones producing intense and mild precipitation events. Section 5 provides a brief summary and the main conclusions of this study.

\section{Data and methods}

Daily precipitation (RR) time series of 15 stations (Fig. 1) have been selected from the ECA dataset. The choice includes long time series that are geographically representative of various areas along the Mediterranean coast. The ECA dataset ${ }^{1}$ (European Climate Assessment; Klein Tank et., 2002; Van Engelen et al., 2008; Haylock et al., 2008; Van den Besselaar et al., 2011) contains blended and non-blended time series. In blended time series, missing values have been filled using data from nearby stations. In this study we have used 15 quality-controlled (which have passed four simple homogeneity tests: standard normal homogeneity test, Buishand range test, Pettitt and Von Neumann ratio test; Van Engelen et al., 2008 and references therein), non-blended time series, which possibly have gaps, but contain only observed values. Table 1 contains the list of the 15 selected time series, with their geographical coordinates and length, that vary among stations. In this study MR has been divided in two large areas: WM (western Mediterranean and $\mathrm{Malaga}^{2}$ ) and EM (eastern Mediterranean), which have been in turn further divided in two smaller parts. WM has been split into NWM (northwestern Mediterranean) and SWM (southwestern Mediterranean). EM has been split into CM (central Mediterranean) and SEM (southeastern Mediterranean). All these details are reported in Table 1 (second column) and Fig. 1.

For the identification of cyclone and the analysis of atmospheric patterns associated with winter precipitations, the SLP fields of the ERA-40 dataset have been used. Data are available for the period 1958-2001 at time intervals of $6 \mathrm{~h}$ on a $127 \times 47$ grid with a $1.125^{\circ}$ step, extending approximately from $81^{\circ} \mathrm{W}$ to $40^{\circ} \mathrm{E}$ and from $19^{\circ}$ to $55^{\circ} \mathrm{N}$. This study uses also the time series of relative humidity (HUMR) and geopotential height at $500 \mathrm{hPa}(\mathrm{Z500})$ of the ERA-40 reanalysis. All data used are anomalies with respect to the mean winter

\footnotetext{
${ }^{1}$ ECA is hosted at the Royal Netherlands Meteorological Institute (KNMI) and has been developed in the framework of the ECA\&D project, a cooperative project whose aim is the implementation of a sustainable operational system for gathering and archiving long-term daily resolution climatic data from meteorological stations throughout Europe.

2 Malaga is included in WM, in spite of its southern location, because it is analogously affected by Atlantic cyclones (see Sect. 3.3).
}

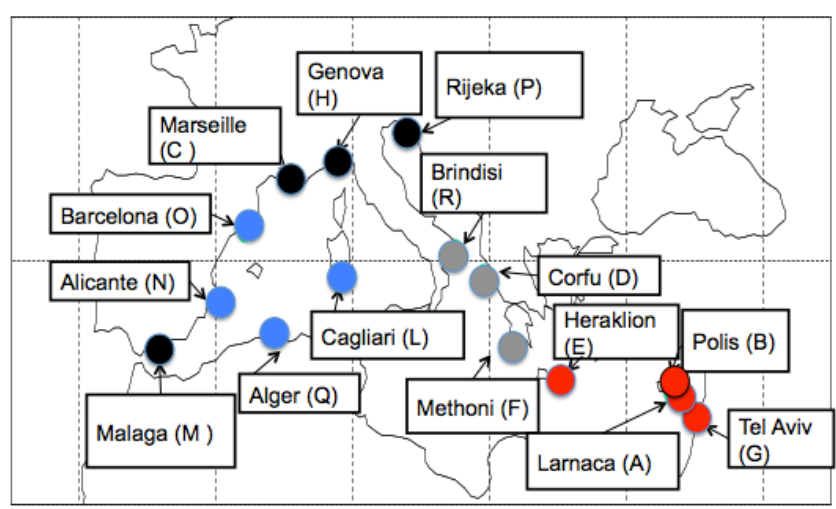

Fig. 1. Map of the Mediterranean region with the stations selected for this study and the labels used for denoting them in the text and figures of this paper. Color codes denotes the different areas. WM (western Mediterranean) has been split in NWM (northwestern Mediterranean and Malaga, black) and SWM (southwestern Mediterranean, light blue). EM (eastern Mediterranean) has been split in CM (central Mediterranean, gray) and SEM (southeastern Mediterranean, red).

cycle over the period 1958-2001 (as in Toreti et al., 2010). Appendix A contains a short description of the applied tracking algorithm and of the quantities that it evaluates.

\section{Characterization of precipitation events}

\subsection{Values and trends of precipitation events}

In this study a "precipitation event" has been defined as a continuous sequence of wet days (daily rainfall above $1 \mathrm{~mm}$ ) that is likely caused by the same synoptic conditions (Reiser and Kutiel, 2012). The intensity of the event is measured by the total accumulated precipitation during its whole duration. Long periods with multiple precipitation maxima are split at day $j$ in sets of shorter events if daily precipitation $\mathrm{RR}_{j}$ is lower than $0.5 \min \left(\mathrm{RR}_{j+1}, \mathrm{RR}_{j-1}\right)$. In other words, if the two rainy days $j-1$ and $j+1$ are separated by a day $j$ with low precipitation (precisely lower than $50 \%$ of the lowest), then the first precipitation event terminates on day $j$, and day $j+1$ is assumed to be the first day of a second event. A list of precipitation events has been produced for each selected location and the empirical $q$ percentile thresholds $\mathrm{Th}_{q}$ have been derived using a method based on the interpolation of the inverse of empirical distribution function (Hyndman and Fan, 1996 and references therein). Four values of $q$ have been considered: 25p, 50p, 90p and 98p. The values of $\mathrm{Th}_{25}, \mathrm{Th}_{50}$, Th 90 and Th 98 are shown in Fig. 2.

The highest values of $\mathrm{Th}_{25}$ (Fig. 2a) and $\mathrm{Th}_{50}$ (Fig. 2b) are found at Rijeka (5 $\mathrm{mm}$ and $17 \mathrm{~mm}$, respectively), of Th 90 (Fig. 2c) and $\mathrm{Th}_{98}$ (Fig. 2d) in Genova $(68 \mathrm{~mm}$ and $140 \mathrm{~mm}$, respectively), the lowest at Alicante $(1 \mathrm{~mm}, 4 \mathrm{~mm}$, $21 \mathrm{~mm}$ and $45 \mathrm{~mm}$ ) for all thresholds. Precipitation events are 
Table 1. Stations selected for this study, along with longitude, latitude and period covered by the data. Macro regions: WM= western Mediterranean, EM= eastern Mediterranean. Micro regions: NWM= northwestern Mediterranean, SWM= southwestern Mediterranean, $\mathrm{CM}=$ central Mediterranean, $\mathrm{SEM}=$ southeastern Mediterranean. The analysis has been restricted to the winter season (DJF: DecemberJanuary-February) in the period 1958-2001.

\begin{tabular}{lllrll}
\hline STATION & REGION & LABEL & \multicolumn{1}{c}{ LONG. } & LAT. & \multicolumn{1}{l}{ PERIOD } \\
\hline LARNACA (CYPRUS) & EM (SEM) & A & $33.28^{\circ} \mathrm{E}$ & $34.55^{\circ} \mathrm{N}$ & $1915-2010$ \\
POLIS (CYPRUS) & EM (SEM) & $\mathrm{B}$ & $33.26^{\circ} \mathrm{E}$ & $35.02^{\circ} \mathrm{N}$ & $1915-2010$ \\
MARSEILLE OBS (FRANCE) & WM (NWM) & $\mathrm{C}$ & $5.23^{\circ} \mathrm{E}$ & $43.28^{\circ} \mathrm{N}$ & $1881-2010$ \\
CORFU (GREECE) & EM (CM) & $\mathrm{D}$ & $19.55^{\circ} \mathrm{E}$ & $39.37^{\circ} \mathrm{N}$ & $1955-2010$ \\
HERAKLION (GREECE) & EM (SEM) & $\mathrm{E}$ & $25.11^{\circ} \mathrm{E}$ & $35.20^{\circ} \mathrm{N}$ & $1955-2010$ \\
METHONI (GREECE) & EM (CM) & $\mathrm{F}$ & $21.42^{\circ} \mathrm{E}$ & $36.50^{\circ} \mathrm{N}$ & $1956-2010$ \\
TEL AVIV (ISRAEL) & EM (SEM) & $\mathrm{G}$ & $32.05^{\circ} \mathrm{E}$ & $34.48^{\circ} \mathrm{N}$ & $1938-2010$ \\
GENOVA (ITALY) & WM (NWM) & $\mathrm{H}$ & $9.00^{\circ} \mathrm{E}$ & $44.24^{\circ} \mathrm{N}$ & $1833-2010$ \\
BRINDISI (ITALY) & EM (CM) & $\mathrm{R}$ & $17.56^{\circ} \mathrm{E}$ & $40.38^{\circ} \mathrm{N}$ & $1951-2010$ \\
CAGLIARI (ITALY) & WM (SWM) & $\mathrm{L}$ & $9.03^{\circ} \mathrm{E}$ & $39.14^{\circ} \mathrm{N}$ & $1951-2010$ \\
ALGER-DAR EL BEIDA (ALGERIA) & WM(SWM) & $\mathrm{Q}$ & $3.15^{\circ} \mathrm{E}$ & $36.43^{\circ} \mathrm{N}$ & $1940-2010$ \\
MALAGA (SPAIN) & WM (NWM) & $\mathrm{M}$ & $-4.29^{\circ} \mathrm{W}$ & $36.40^{\circ} \mathrm{N}$ & $1942-2010$ \\
ALICANTE EL ALTET (SPAIN) & WM(SWM) & $\mathrm{N}$ & $0.29^{\circ} \mathrm{E}$ & $38.21^{\circ} \mathrm{N}$ & $1967-2010$ \\
BARCELONA (SPAIN) & WM(SWM) & $\mathrm{O}$ & $02.07^{\circ} \mathrm{E}$ & $41.25^{\circ} \mathrm{N}$ & $1927-2010$ \\
RIJEKA (CROATIA) & WM (NWM) & $\mathrm{P}$ & $14.27^{\circ} \mathrm{E}$ & $45.19^{\circ} \mathrm{N}$ & $1947-2010$ \\
\hline
\end{tabular}
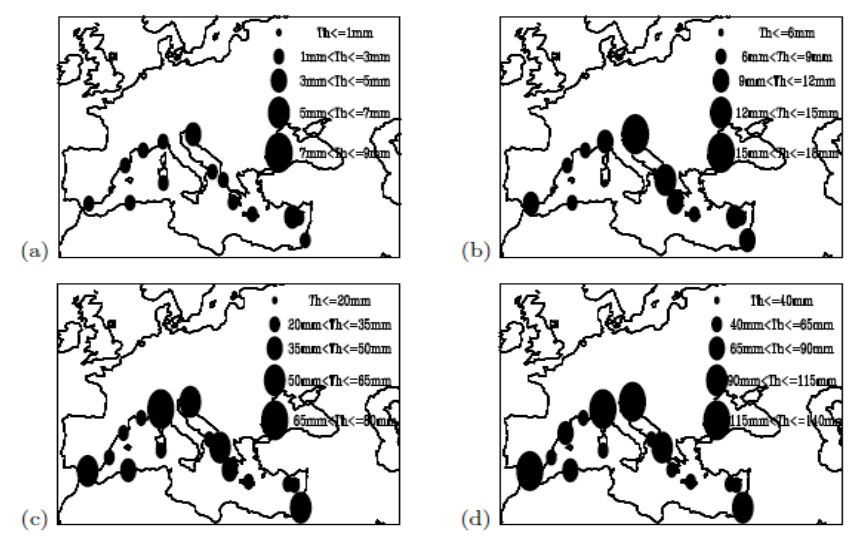

Fig. 2. $\mathrm{Th}_{25}$ (a), $\mathrm{Th}_{50}$ (b), $\mathrm{Th}_{90}$ (c) and $\mathrm{Th}_{98}$ (d) in the considered stations. Values (in $\mathrm{mm}$ ) are reported in the panels and are proportional to the radius of the dots.

grouped into 4 categories depending on intensity: $\mathrm{C}_{25}$ containing $\mathrm{N}_{25}$ events from $\mathrm{Th}_{25}$ to $\mathrm{Th}_{50}, \mathrm{C}_{50}$ containing $\mathrm{N}_{50}$ events from $\mathrm{Th}_{50}$ to $\mathrm{Th}_{75}, \mathrm{C}_{90}$ containing $\mathrm{N}_{90}$ events from $\mathrm{Th}_{90}$ to $\mathrm{Th}_{98}$, and $\mathrm{C}_{98}$ containing $\mathrm{N}_{98}$ events above $\mathrm{Th}_{98}$. The mean number of events $\mathrm{N}_{p}$ for decade for each category is shown in Fig. 3. The highest numbers of events for decade for each threshold has been detected in time series of Methoni (49, 98, 19 and 3, respectively), the lowest in Alicante (17, 35, 7 and 1, respectively), which has also the lowest number of valid data.

Figures 2 and 3 show that differences in the values of $\mathrm{Th}_{p}$ and in the number of events among stations are large. These results reflect the variability of precipitation regime in the $\mathrm{MR}$, which is due to mesoscale and local factors and is partic-
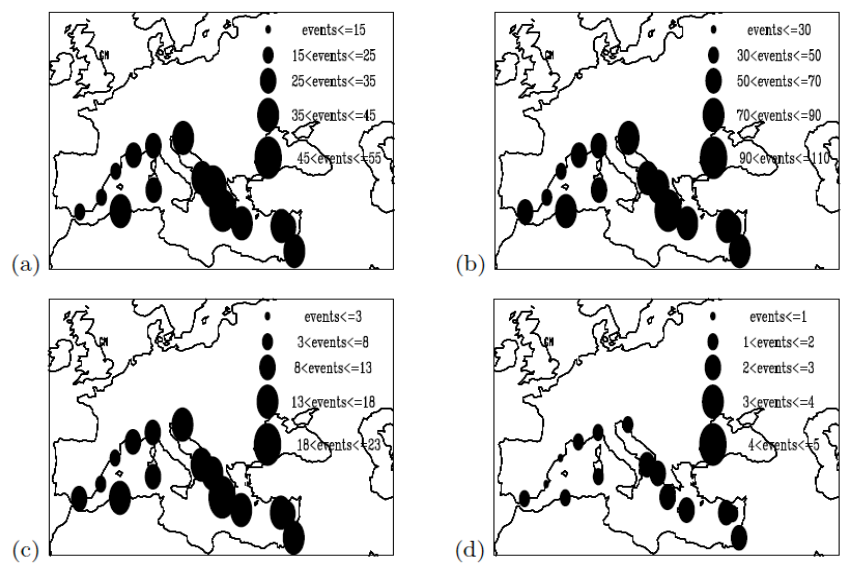

Fig. 3. Same as Fig. 2 except it shows the mean number of events $\mathrm{N}_{25}$ (a), $\mathrm{N}_{50}$ (b), $\mathrm{N}_{90}$ (c) and $\mathrm{N}_{98}$ (d). Values are in number of events / decade.

ularly important in areas with complicated topography near the coast (Türkeş, 1998; Xoplaki et al., 2006). However, gaps in the time series and differences in the covered time periods might also have produced some differences among stations. An estimation of trend in each time series has been given using the non parametric Theil-Sen (or Sen's slope) method (Theil, 1950; Sen, 1968). The Mann-Kendall test applied to the time series of annual values of $\mathrm{N}_{25}, \mathrm{~N}_{90}$ and $\mathrm{N}_{98}$ (as in Fig. 3) shows no significant trend at the the $90 \%$ confidence level. For $\mathrm{N}_{50}$ a generalized statistically significant decrease is observed, with no station showing a positive trend (Fig. 4).

Note that also analyses of accumulated winter precipitation time series are mildly suggestive of a decrease 


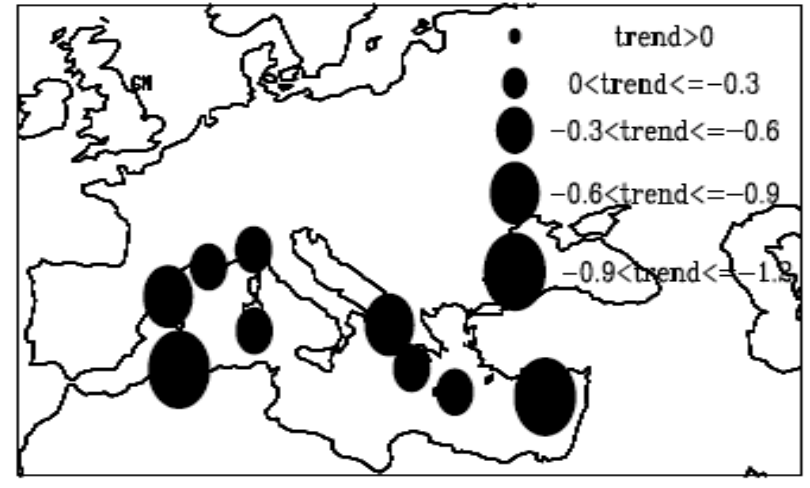

Fig. 4. Location and magnitude of significant trends observed in $\mathrm{N}_{50}$. Values are in number of events/decade.

during the second half of the 20th century (not shown). Ten out of the fifteen considered stations do not show a significant (at the $90 \%$ confidence level) trend in winter total precipitation, while four stations show a significant negative trend (Larnaca, Polis, Corfu and Cagliari), and only one (Alicante) a significant positive trend. Negative trends range from the largest decrease of $-4.37 \mathrm{~mm} \mathrm{yr}^{-1}$ (Corfu) to $-1.37 \mathrm{~mm} \mathrm{yr}^{-1}$ (Larnaca). The negative trends in Polis and Cagliari are comparable $\left(-1.79 \mathrm{~mm} \mathrm{yr}^{-1}\right.$ and $-1.66 \mathrm{~mm} \mathrm{yr}^{-1}$, respectively). The time series in Alicante is characterized by about $3 \%$ missing data mainly in the period 1958-1981, which may affect the robustness of its significant positive trend $\left(1.77 \mathrm{~mm} \mathrm{yr}^{-1}\right)$.

\subsection{Teleconnection patterns}

An analysis has been carried out to show whether the four categories of events (as defined in the previous subsection) are associated with anomalous phases of the Northern Hemisphere teleconnection patterns (NHTP) influencing Mediterranean climate (NAO, EA, EAWR and SCAN) ${ }^{3}$.

For each location and for each class, two sets containing months with high and low frequency of events ${ }^{4}$ (called $M^{+}$and $M^{-}$) have been identified. The definition of the two sets is based on the mean $\mu_{q}$ and the standard deviation $\sigma_{q}$ of the monthly frequency of $\mathrm{N}_{25}, \mathrm{~N}_{50}, \mathrm{~N}_{90}$ and $\mathrm{N}_{98}$. The set $M^{+}$include months with frequency larger than $\mu_{q}+\sigma_{q}$, and $M^{-}$for those with less that $\mu_{q}-\sigma_{q}$ or no events. For $\mathrm{C}_{98}$ the set $M+$ contains the months in which there is at least one event, and $M-$ for those with no event. Mean values of the index of each NHTP in the $M^{+}$and $M^{-}$sets denoted as $<\operatorname{NHTP}\left(M^{+}\right)>$and $<\operatorname{NHTP}\left(M^{-}\right)>$have been computed. Figures $5-8$ show for each category $\left(\mathrm{C}_{25}, \mathrm{C}_{50}\right.$,

\footnotetext{
${ }^{3}$ The time series of NHTP indexes are available at the NOAA (National Oceanic and Atmospheric Administration) Climate Prediction Center http://www.cpc.ncep.noaa.gov/data/teledoc/ telecontents.shtmeach.

${ }^{4}$ Each event has been attributed to the month in which it begins.
}

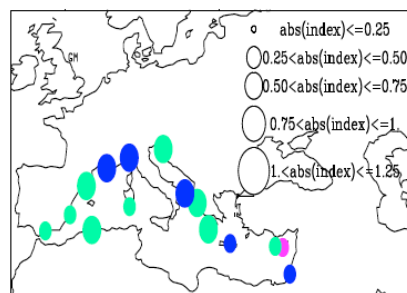

(a)

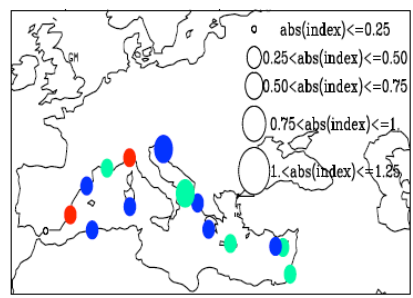

(b)
Fig. 5. NHTP presenting the largest (a) and second largest (b) statistical link with $\mathrm{C}_{25}$ events (see Table 2 for the interpretation of the color codes). The size of the bullets shows the strength of the link. It is proportional to the difference between the mean value of the NHTP indexes in months with high and low frequency of $\mathrm{C}_{25}$ events. All colored dots report values that are significant at the $90 \%$ confidence level according to Mann-Whitney test. Absence of any significant link is denoted with small empty circles.

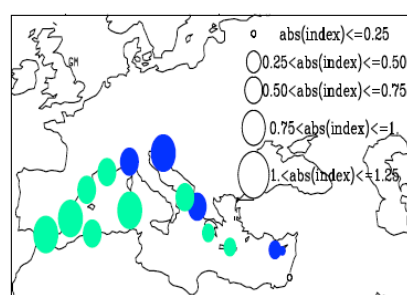

(a)

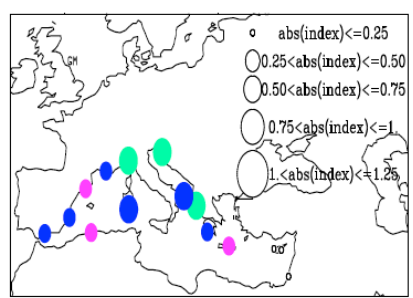

(b)
Fig. 6. As Fig.5 except for $\mathrm{N}_{50}$.

$\left.\mathrm{C}_{90}, \mathrm{C}_{98}\right)$ the differences $<\operatorname{NHTP}\left(M^{+}\right)>-<\operatorname{NHTP}\left(M^{-}\right)>$ in order to describe which patterns and which phase exert the largest influence on precipitation. Precisely, they show the patterns with the largest (left panel) and second largest (right panel) absolute value of the difference $<\operatorname{NHTP}\left(M^{+}\right)>$ $-<\operatorname{NHTP}\left(M^{-}\right)>$. The color codes for the interpretation of Figs. 5-8 are reported in Table 2. For instance, green dots denote that the difference $<\mathrm{NAO}\left(M^{+}\right)>-<\mathrm{NAO}\left(M^{-}\right)>$is negative and therefore, in stations denoted with green dots, NAO- is the first (left panel) or second (right panel) most important pattern favoring precipitation events. The size of the bullets is proportional to the difference between the mean value of the NHTP indexes in months with high and low frequency of $\mathrm{C}_{25}$ events and shows the strength of the statistical link.

Figures 5-7 clearly show that NAO- and EAWR- are the patterns (and phases) favoring precipitation events, with the influence of NAO- being most important in the western Mediterranean and that of EAWR- in the central part. EAhas also a non-negligible role, being the second most important pattern for $\mathrm{C}_{50}$ and $\mathrm{C}_{90}$ events in several locations. The behavior of $\mathrm{C}_{25}, \mathrm{C}_{50}$ and $\mathrm{C}_{90}$ events is substantially similar, while $\mathrm{C}_{98}$ events behave quite differently, and in most locations they cannot be associated with the phase of any NHTP. This means there is not robust link with the NHTPs. 
Table 2. Color codes for the interpretation of Figs. 5-8. First column reports the color used to denote the bullets in Figs. 5-8, the second column the associated statistical result, and the third column the associated NHTP and phase.

\begin{tabular}{lll}
\hline COLOR & STATISTICS & NHTP \\
\hline BLACK & $<\operatorname{NAO}(M+)>-<\operatorname{NAO}(M-)>$ positive & NAO+ \\
GREEN & $<\operatorname{NAO}(M+)>-<\operatorname{NAO}(M-)>$ negative & NAO- \\
FUCHSIA & $<\operatorname{EA}(M+)>-<\operatorname{EA}(M-)>$ negative & EA- \\
RED & $<\operatorname{EA}(M+)>-<\operatorname{EA}(M-)>$ positive & EA+ \\
BLUE & $<\operatorname{EAWR}(M+)>-<\operatorname{EAWR}(M-)$ negative & EAWR- \\
ORANGE & $<\operatorname{EAWR}(M+)>-<\operatorname{EAWR}(M-)$ negative & EAWR+ \\
YELLOW & $<\operatorname{SCAN}(M+)>-<\operatorname{SCAN}(M-)>$ negative & SCAN- \\
VIOLET & $<\operatorname{SCAN}(M+)>-<\operatorname{SCAN}(M-)>$ positive & SCAN+ \\
\hline
\end{tabular}

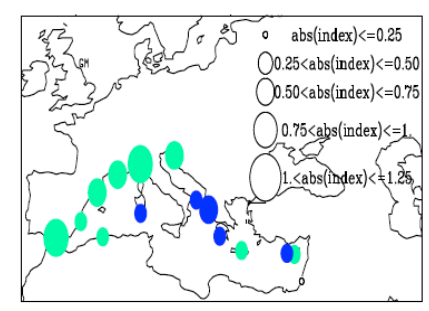

(a)

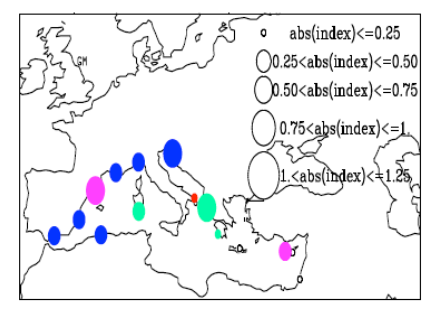

(b)
Fig. 7. As Fig. 5 except for $\mathrm{N}_{90}$.

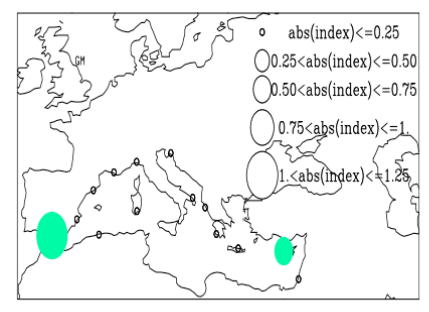

(a)

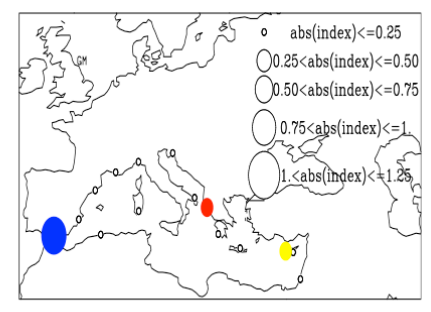

(b)
Fig. 8. As Fig. 5 except for $\mathrm{N}_{98}$.

\subsection{Cyclones producing intense precipitation events}

This section describes the cyclones that are associated with winter precipitation events whose intensity is larger than $\mathrm{Th}_{98}\left(\mathrm{~N}_{98}\right)$. They are denoted as $\mathrm{C}_{98}$ or "intense" events in this manuscript. "Intense" is preferred to "extreme" as they are not as rare as the events usually considered in extreme value theory. Table 3 reports the return times, defined as the inverse of the average annual number of events in each location, and shows its large variability: the longest return time is observed in Alicante (7.33) and Barcelona (6.28); the shortest in Methoni and Corfu (2.58 and 2.93). Return times obviously reflect the different number of events in the various stations, which is maximum in the two Ionian Greek stations and minimum in the two Spanish stations.

The cyclone associated with a precipitation event is that whose SLP minimum is nearest to the considered station at 12:00 UTC of the day when the largest precipitation during
Table 3. Return time (in years) for $\mathrm{C}_{98}$ events for each location.

\begin{tabular}{ll}
\hline STATION & $\begin{array}{l}\text { Return } \\
\text { Time }\end{array}$ \\
\hline LARNACA & 3.66 \\
POLIS & 3.73 \\
MARSEILLE & 4.40 \\
CORFU & 2.93 \\
HERAKLION & 3.14 \\
METHONI & 2.58 \\
TEL AVIV & 3.14 \\
GENOVA & 4.40 \\
BRINDISI & 3.14 \\
CAGLIARI & 3.66 \\
ALGER & 3.38 \\
MALAGA & 4.88 \\
ALICANTE & 7.33 \\
BARCELONA & 6.28 \\
RIJEKA & 3.38 \\
\hline
\end{tabular}

the whole event occurs. In this study only SLP minima within a distance lower than $20^{\circ}$ (about $2000 \mathrm{~km}$ ) from the station are considered. Results confirm the former analysis of Jansà et al. (2001b) and the strong association between cyclones and winter precipitation. Figure 9a shows the rate of success of the procedure searching for the nearest cyclone for the different classes of events $\left(\mathrm{N}_{25}, \mathrm{~N}_{50}, \mathrm{~N}_{90}\right.$ and $\left.\mathrm{N}_{98}\right)$ and the results of the identical procedure applied for dry days located in the center of dry periods of increasing length (from 1 to 11 days). In general, the probability of detecting a cyclone within a distance of $20^{\circ}$ from each station increases with the intensity of the precipitation event and decreases with the duration of a dry period. During intense precipitation events the rate of success of the procedure is high and relatively uniform for all stations. During dry days there is a large geographical difference among stations. For Genova, Barcelona, Rijeka and Marseille, probably because of their proximity to the main branch of the storm track across Europe, it is rather likely to find a cyclone inside the $20^{\circ}$ search radius even during dry days. Some optimization of the statistics could be 

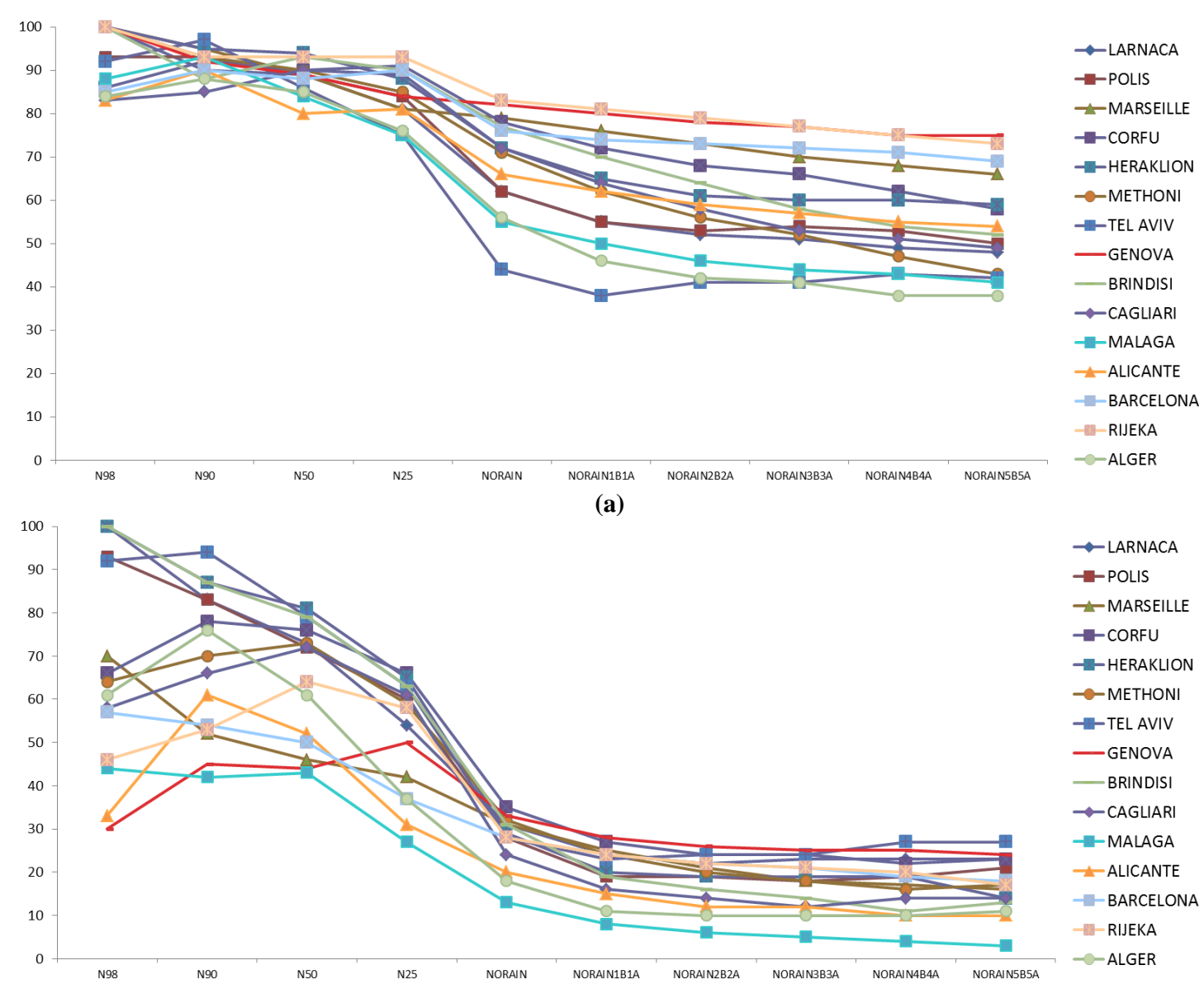

(b)

Fig. 9. Frequency (\%, y-axis) of detecting a cyclone within a distance of $20^{\circ}$ (a) and $10^{\circ}$ (b) from the stations considered in this study. The frequency has been computed during events of increasing intensity $\left(\mathrm{N}_{25}, \mathrm{~N}_{50}, \mathrm{~N}_{90}\right.$ and $\left.\mathrm{N}_{98}\right)$ and for dry periods of increasing duration $(1,3,5,7,9$ and 11 days).

possibly obtained adopting a different search radius depending on location. Figure $9 \mathrm{~b}$ shows the results obtained with a $10^{\circ}$ search radius. For dry days this small search radius dramatically reduces the number of cyclones in the statistics. For intense precipitation events there are stations such as Brindisi, Polis, Heraklion and Tel Aviv, where adopting a smaller search radius produces very little difference. In these stations, the radius of the cyclones is generally rather small and cyclones associated with precipitation are well-defined isolated features within the Mediterranean region. In northern Mediterranean stations, such as Rijeka, Genova and Marseille, adopting a smaller radius would produce a high percentage of failure during precipitation events for two reasons. When orographic cyclogenesis occurs, the small isolated minimum situated to the south of a large cyclone over northern Europe is not always detected as an independent system by the tracking algorithm in its early stages. Further, many intense cyclones crossing northern Europe have a very large radius and actually affect atmospheric circulation (and precipitation) in the northern Mediterranean areas even though their center's located is a large distance away. In this study, the $20^{\circ}$ search radius has been preferred because it leads to a reasonable identification of cyclones for intense precipitation events.

Figure 10 shows the tracks of cyclones producing intense precipitation in the NWM stations Malaga, Marseille, Genova and Rijeka. All cyclones producing severe precipitation in Malaga are originated over North Atlantic, while in Marseille, Genova and Rijeka precipitation is associated either with Atlantic systems moving along the main midlatitude storm track or with cyclones originated over the Mediterranean Sea itself.

For CM stations, most cyclones producing severe precipitations move along the Mediterranean branch of the storm track. Figure 11 shows cyclones producing intense precipitation events at Brindisi, Corfu and Methoni. These cyclones are originated mostly over northern Italy and the Gulf of Genova and then move southeastward. This result is consistent with the well-known importance of orographic 


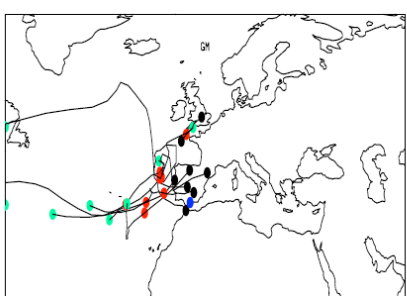

(a) MALAGA

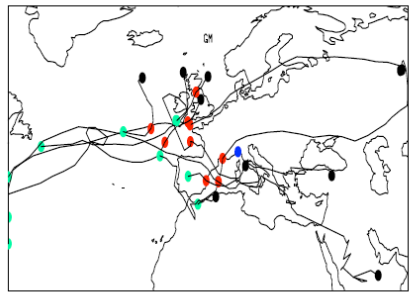

(c) GENOVA
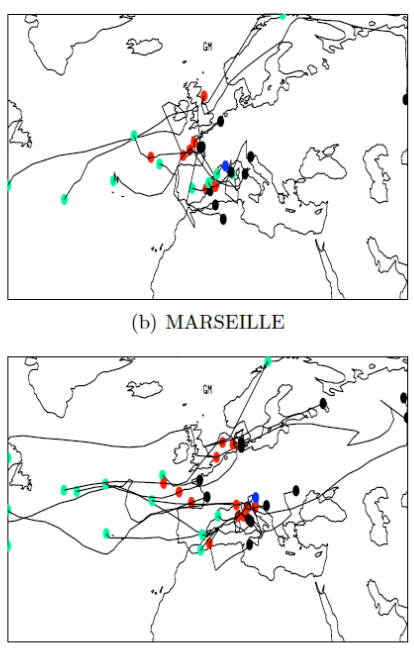

(d) RIJEKA (b) MARSEILLE

Fig. 10. Trajectories of cyclones in the $\mathrm{C}_{98}$ category at Malaga, Marseille, Genova and Rijeka (panels are denoted with the name of station, blue dots denote the station position) producing precipitation events above Th98. The red dots show the position in the day of maximum precipitation, the green/black dots the locations of cyclogenesis/cyclolysis.

cyclogenesis in winter over these areas (see, e.g, Lionello et al., 2006b, and Ulbrich et al., 2012, for a review).

Intense precipitation in SEM stations (Heraklion, Polis, Larnaca and Tel Aviv; Fig. 12) is almost exclusively associated with cyclones in the Mediterranean storm track, with many of them being originated above the Levantine Basin (Cyprus lows or Cyprus depressions, Krichak et al., 2004) migrating afterwards to the east along very short tracks.

Finally, an important fraction of severe precipitation in the SWM (Alicante, Barcelona, Alger and Cagliari, Fig. 13) is produced by cyclones generated over northern Africa. This is an interesting result because cyclogenesis over northern Africa is not frequent in winter and takes place mainly in spring and summer (Lionello et al., 2006b).

In conclusion, Atlantic lows dominate over NWM. These cyclones are characterized by the longest lifetime (clearly shown by the longest tracks) and either move along the midlatitude storm track or move across the Mediterranean region along the direction northwest-southeast. Cyclogenesis over the NWM is important for producing severe precipitation over $\mathrm{CM}$ with cyclones moving along the Mediterranean storm tracks from west (northern Italy) to southeast towards Greece and Albania. In SEM, intense rain is mostly produced by Cyprus lows (Krichak et al., 2004). Cyclones observed in both CM and SEM are characterized by shorter tracks and shorter lifetime with respect to the Atlantic lows affecting NM (Lionello et al., 2006b).

Anomaly fields (with respect to the winter mean) of SLP, Z500 and HUMR associated with intense events have been analyzed. The "mean" SLP distribution during the peak of

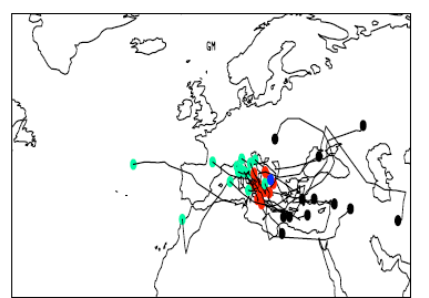

(a) BRINDISI

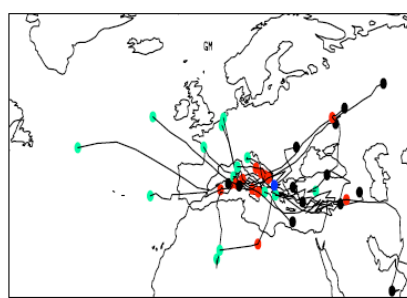

(b) $\mathrm{CORFU}$

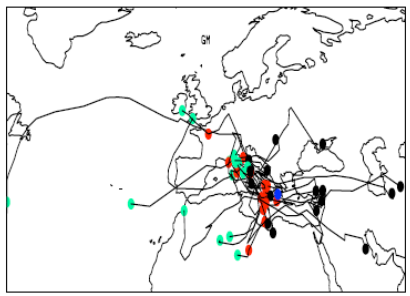

(c) METHONI

Fig. 11. Same as Fig. 10 except it refers to Brindisi, Corfu and Methoni.
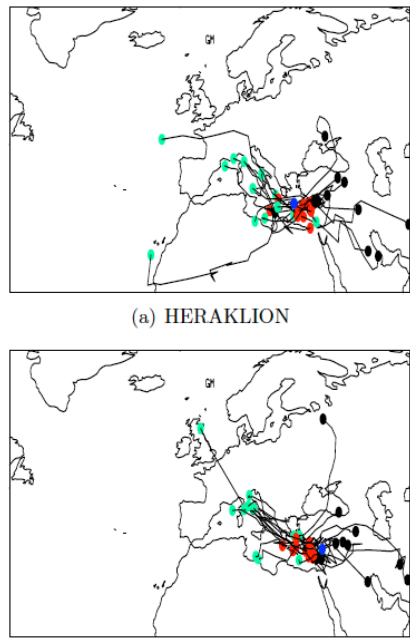

(c) LARNACA (a) HERAKLION

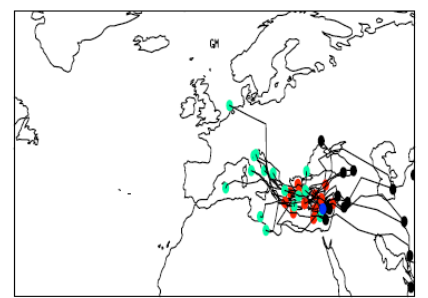

(b) POLIS

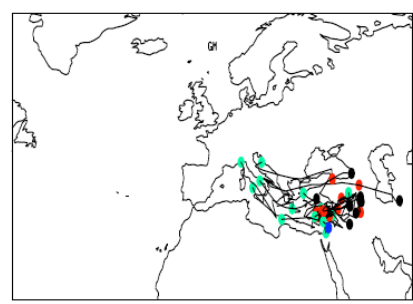

(d) TEL AVIV
Fig. 12. Same as 10 except it considers Heraklion, Polis, Larnaca and Tel Aviv.

events is shown in Fig. 14, which displays the composite of the SLP fields at 12:00 UTC of the day with largest precipitation within each intense event. The SLP pattern shows clearly the presence of a cyclone, which is generally located in a position that favors advection of humid air towards the location where precipitation occurs (Jansà et al., 2001a; Lionello et al., 2006b). The features in the SLP composites are rather broad when they include cyclones whose centers are located over a wide area. An example is Rijeka (Fig. 14d), where composites include cyclones located over the eastern Atlantic and over the northwest Mediterranean Sea. Similar considerations are valid for Alger and Cagliari as well (Fig. 14g and $\mathrm{h}$, respectively). 


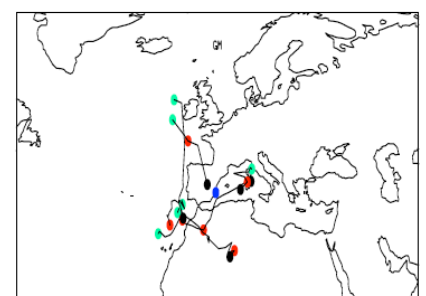

(a) ALICANTE

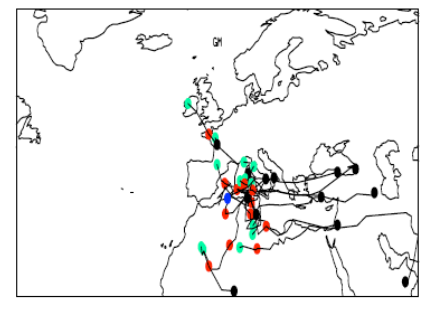

(c) ALGER

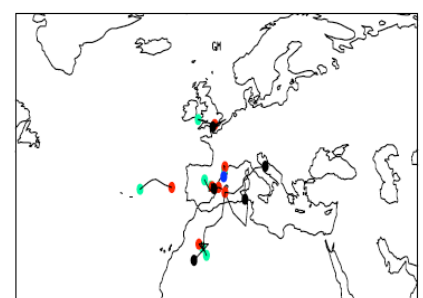

(b) BARCELONA

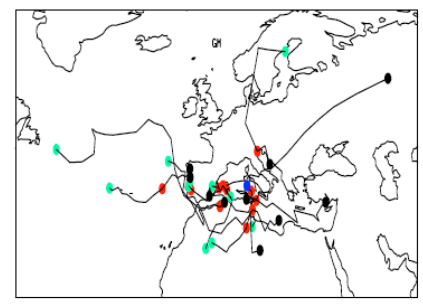

(d) CAGLIARI
Fig. 13. Same as Fig. 10 except it shows Alicante, Barcelona, Alger and Cagliari.

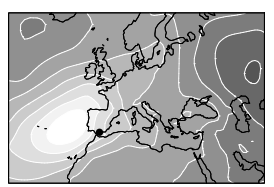

(a) MALAGA

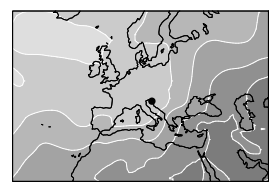

(d) RIJEKA

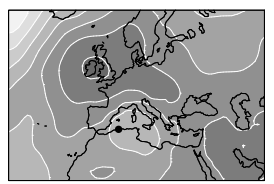

(g) ALGER

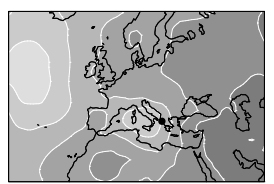

(j) $\mathrm{CORFU}$

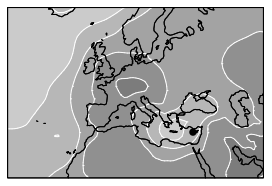

(m) POLIS

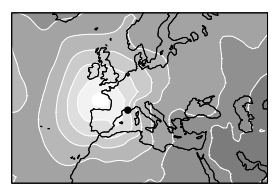

(b) MARSEILLE

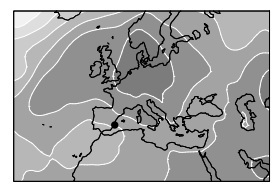

(e) ALICANTE

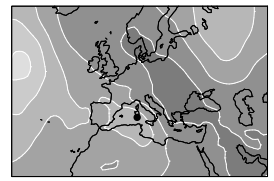

(h) CAGLIARI

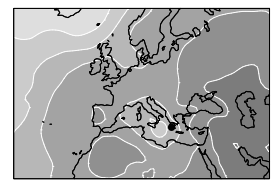

(k) METHONI

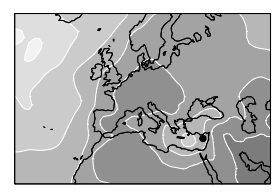

(n) LARNACA

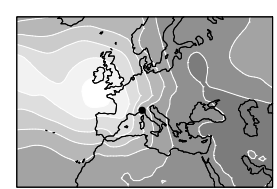

(c) GENOVA

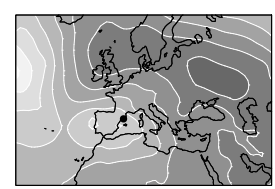

(f) BARCELONA

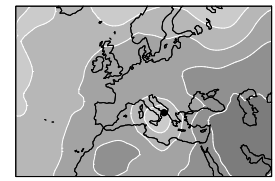

(i) BRINDISI

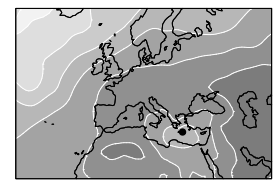

(1) HERAKLION

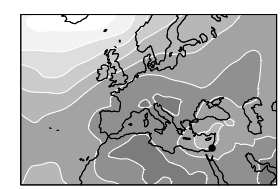

(o) TEL AVIV

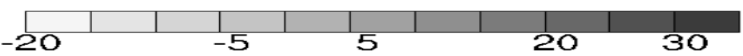

Fig. 14. Composite of SLP anomalies (in hPa) based on fields at 12:00 UTC on the day with largest precipitation of each intense event in the 15 stations considered in this study. The position (black dot) where intense precipitation has been recorded is reported in each panel.

\section{Peculiarities of cyclones producing severe precipitation}

This section aims at identifying the peculiar characteristics of cyclones producing severe precipitation events that make them possibly different from other cyclones. For this purpose, the synoptic conditions during precipitation events whose intensity belongs to the upper and lower tails of the distribution are compared. The two classes of cyclones analyzed in this section are those in the range of the 2550 percentile $\left(\mathrm{C}_{25}\right.$, "mild" events) and above the 90 percentile $\left(\mathrm{C}_{90+98}\right.$, including $\mathrm{C}_{90}$ "severe" events and $\mathrm{C}_{98}$ "intense" events). Unfortunately, the $\mathrm{C}_{98}$ category alone (used in the previous section for intense cyclones) contains too few events for a robust statistical analysis and it cannot be adopted for this comparison. 


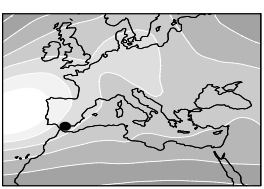

(a) MALAGA

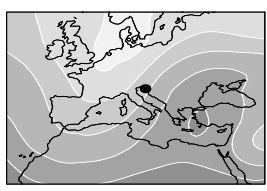

(d) RIJEKA

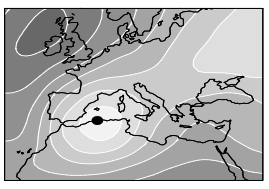

(g) ALGER

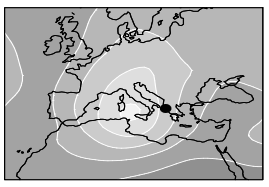

(j) CORFU

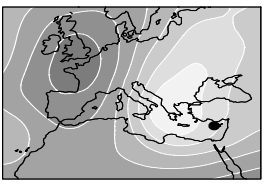

(m) POLIS

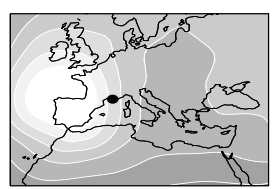

(b) MARSEILLE

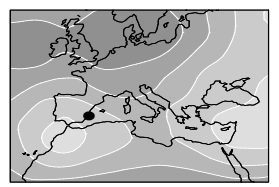

(e) ALICANTE

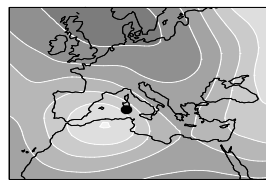

(h) CAGLIARI

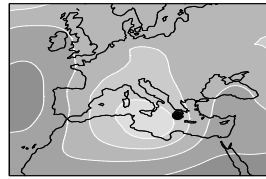

(k) METHONI

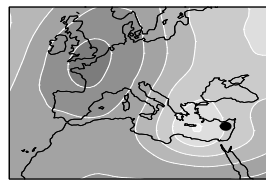

(n) LARNACA

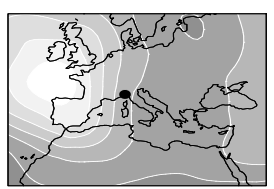

(c) GENOVA

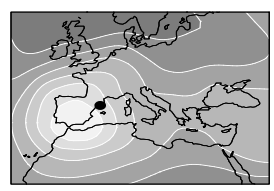

(f) BARCELONA

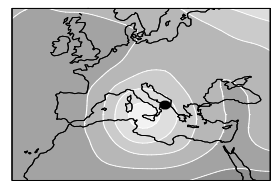

(i) BRINDISI

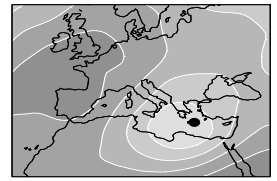

(1) HERAKLION

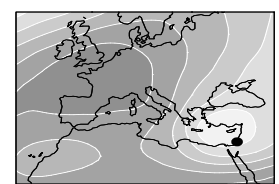

(o) TEL AVIV

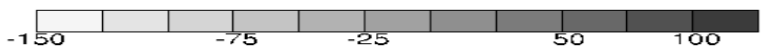

Fig. 15. Same as Fig. 14 except it shows anomalies of Z500, geopotential height $(\mathrm{m})$ at $500 \mathrm{hPa}$.

Figures 17-18 show the differences between composites of SLP (in hPa) and Z500 (in m) computed for C25 and C90+98 events, respectively. In most of locations the panels show a dipole structure for both fields. The negative/positive lobe is the area where the fields of $\mathrm{C}_{90+98}$ cyclones are lower/higher than those of the $\mathrm{C}_{25}$ cyclones. Since the negative lobes overlap the SLP/Z500 minima shown in Figs. 1718 , they correspond to an intensification of the cyclones and this means that higher strength of the cyclonic circulation is a characteristic of the $\mathrm{C}_{90+98}$ events. The positive lobe of the dipole is located in such a way that the large gradient in the transition area between the two lobes reinforces the air flow that advects moisture. This means that severe precipitation requires an overall synoptic condition favoring a long wind fetch over sea. The two dipoles have a comparable intensity, meaning that the intensity of the cyclone and the surrounding synoptic condition (possibly the presence of a high-pressure system) have a comparable importance. An example of this situation can be found in the cyclone that produced a catastrophic flood over Italy on 4 November 1966 (De Zolt et al., 2006), where the circulation produced by a cyclone lo-

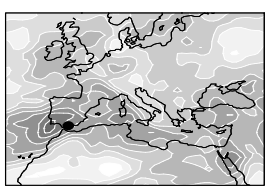

(a) MALAGA

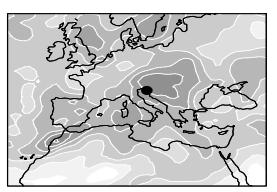

(d) RIJEKA

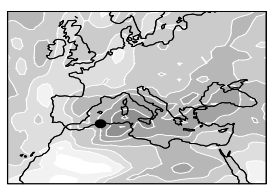

(g) ALGER

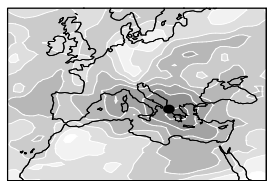

(j) $\mathrm{CORFU}$

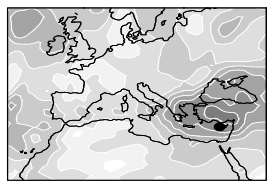

(m) POLIS

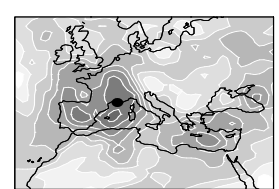

(b) MARSEILLE

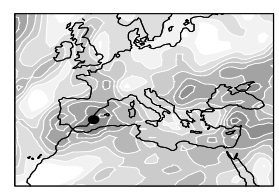

(e) ALICANTE

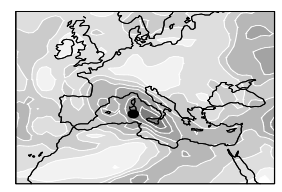

(h) CAGLIARI

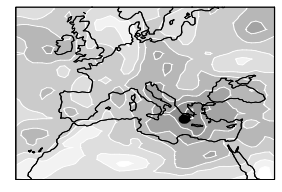

(k) METHONI

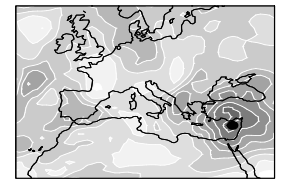

(n) LARNACA

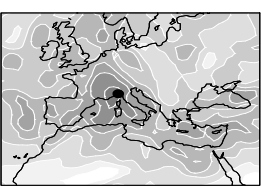

(c) GENOVA

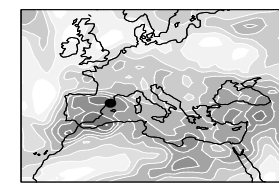

(f) BARCELONA

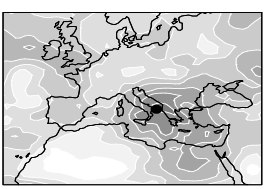

(i) BRINDISI

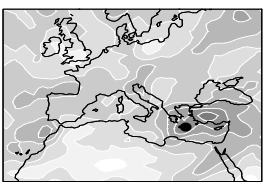

(1) HERAKLION

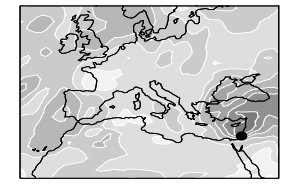

(o) TEL AVIV

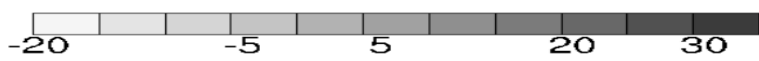

Fig. 16. Same as Fig. 14 except it shows anomalies of HUMR, relative humidity $(\%)$ at $500 \mathrm{hPa}$.

cated west of Italy was reinforced by the presence of a highpressure system over southeastern Europe. The dipole structure is weak in Corfu (D), Methoni (F) and Polis (B), suggesting that for these locations, the depth of the depression is the important factor. Figure 19 shows the difference of relative humidity in the midtroposhere between $\mathrm{C}_{90+98}$ and $\mathrm{C}_{25}$ events. The pattern is rather noisy, but it nonetheless shows that $\mathrm{C}_{90+98}$ events have larger relative humidity values than $\mathrm{C}_{25}$ events in the areas surrounding where events occur.

In order to identify characteristics that describe the differences between the two classes of cyclones, several variables have been considered: depth, extension, speed, Laplacian and gradient of and mean amount of moisture in the cyclone cores. The precise definition of these variables is given in Appendix A. The mean value of these quantities in each location has been computed for $\mathrm{C}_{25}$ and $\mathrm{C}_{90+98}$ cyclones and their difference is reported in Table 4. Bold values denote differences that are statistically significant at the $90 \%$ level according to the Mann-Whitney test.

Table 4 shows that differences are present between $\mathrm{C}_{90+98}$ and $\mathrm{C}_{25}$, but due high variability of the systems they are 


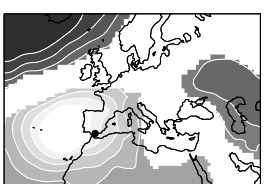

(a) MALAGA

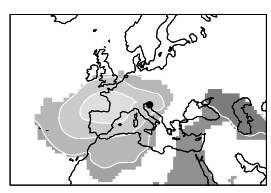

(d) RIJEKA

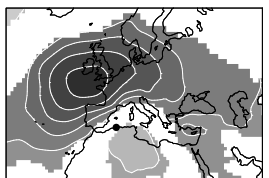

(g) ALGER

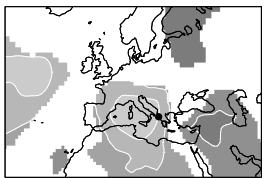

(j) $\mathrm{CORFU}$

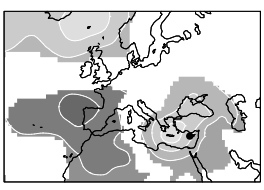

(m) POLIS

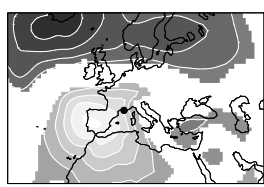

(b) MARSEILLE

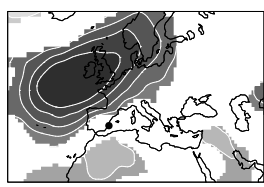

(e) ALICANTE

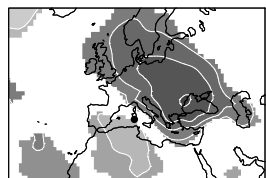

(h) CAGLIARI

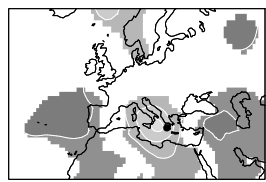

(k) METHONI

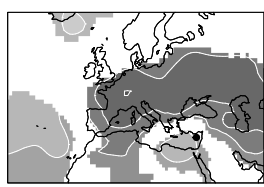

(n) LARNACA

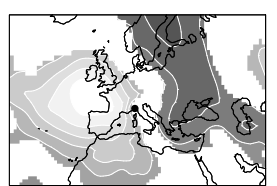

(c) GENOVA

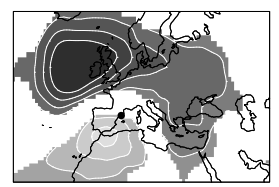

(f) BARCELONA

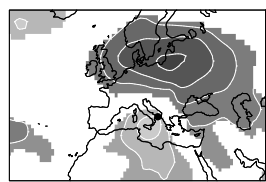

(i) BRINDISI

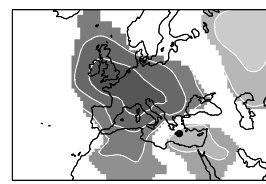

(1) HERAKLION

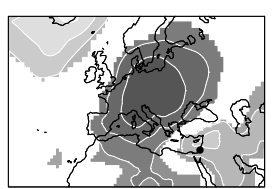

(o) TEL AVIV

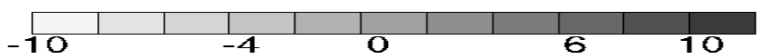

Fig. 17. Difference between composites of the SLP (sea level pressure, $\mathrm{hPa}$ ) fields at 12:00 UTC that are associated with precipitation in the $\mathrm{C}_{90}$ and $\mathrm{C}_{25}$ events. Composites are based on fields at 12:00 UTC on the day with largest precipitation of each event. The maps show only areas where differences are statistically significant at the $90 \%$ confidence level according to the Mann-Whitney test.

not always statistically significant and sometimes sign varies among stations (e.g., for the relative humidity). Actually, having used only the criterion of minimum distance might have led to some false association between precipitation events and cyclones, and adopting more stringent criteria could possibly increase the number of statistically significant values in Table 4. The mean speed of $\mathrm{C}_{90+98}$ cyclones is everywhere (meaning in all stations) slower than that of $\mathrm{C}_{25} \mathrm{cy}-$ clones, and in a half of stations this difference is statistically significant. For mean depth, $\mathrm{C}_{90+98}$ cyclones are everywhere deeper (with the exception of Alicante) than $\mathrm{C}_{25}$ cyclones, and the difference is significant in 11 stations out of 15 . The mean radius of $\mathrm{C}_{90+98}$ cyclones is everywhere larger (with the exception of Corfu) than that of $\mathrm{C}_{25}$ cyclones. Further, $\mathrm{C}_{90+98}$ tend to have stronger circulation than $\mathrm{C}_{25}$ cyclones almost in all cases, with difference significant in 9 stations for both mean Laplacian and gradient. Note that the lack of sig-

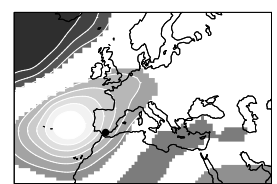

(a) MALAGA

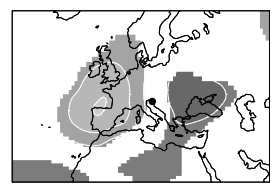

(d) RIJEKA

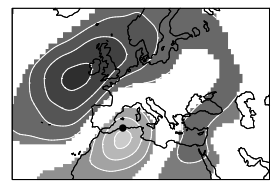

(g) ALGER

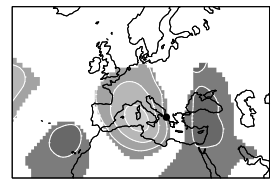

(j) CORFU

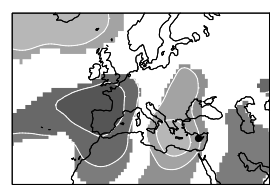

(m) POLIS

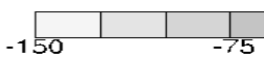

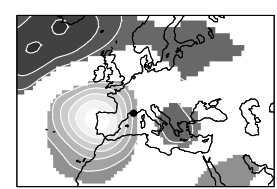

(b) MARSEILLE

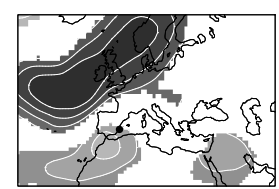

(e) ALICANTE

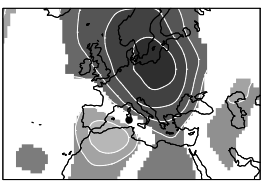

(h) CAGLIARI

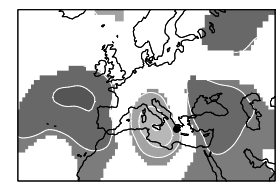

(k) METHONI

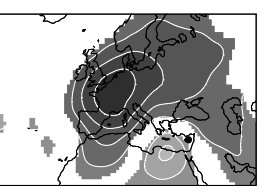

(n) LARNACA

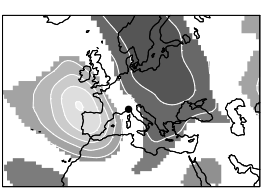

(c) GENOVA

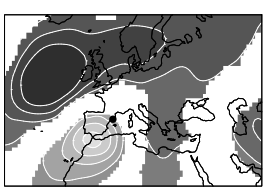

(f) BARCELONA

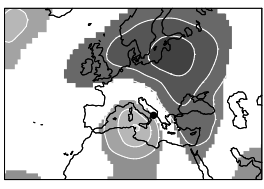

(i) BRINDISI

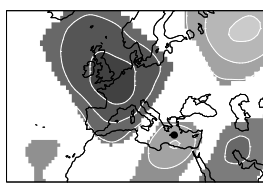

(1) HERAKLION

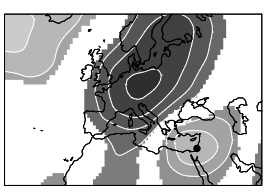

(o) TEL AVIV
Fig. 18. Same as Fig. 17, except it shows the difference between composites of the Z500 (geopotential height, in m) fields.

nificant differences for relative humidity contrasts the visual impression from Fig. 19; this is probably due to the selected area for the computation of this quantity (see Appendix A), which is symmetric around the location of the station, while the patterns of the differences in Fig. 19 are asymmetric, with the location of the maximum being upwind, downwind or laterally shifted depending on the station, such that it is difficult to find a criterion valid for all stations.

Figures 20-22 display graphically the results also reported in Table 4. They are meant to show in a synthetic way the significance of these differences and their coherency among different stations. The figures consider separately west (left panels) and east locations (right panels). Stations are represented with the letters listed in Table 1. For example, in Fig. 20, each bullet in its two panels represents one of the 15 stations that are listed in Table 1. For each location and for $\mathrm{C}_{25}$ and $\mathrm{C}_{90+98}$ cyclones, the average gradient $\left(\mathrm{G}_{25}\right.$ and $\left.\mathrm{G}_{90+98}\right)$ and extension $\left(\mathrm{E}_{25}\right.$ and $\left.\mathrm{E}_{90+98}\right)$ have been computed. Points with $x$ coordinates $\mathrm{G}_{90+98}-\mathrm{G}_{25}$ and $y$ coordinate $\mathrm{E}_{90+98}-\mathrm{E}_{25}$ are plotted in Fig. 20 to show the average difference between the cyclones in the two classes. Bars are proportional to the average 
Table 4. Differences between cyclones in the $\mathrm{C}_{90+98}$ and $\mathrm{C}_{50}$ classes. Table shows the difference for mean values of Laplacian, depth, gradient, extension and speed. Bold characters denote values when difference is statistically significant at the $90 \%$ level.

\begin{tabular}{lrrrrrr}
\hline LOCATION & $\begin{array}{r}\text { LAPLACIAN } \\
\left.\text { (in } 10^{-10} \mathrm{~Pa}^{-2}\right)\end{array}$ & $\begin{array}{r}\text { DEPTH } \\
\text { (in } \mathrm{hPa})\end{array}$ & $\begin{array}{r}\text { GRADIENT } \\
\left(\text { in } 10^{-3} \mathrm{~Pa} \mathrm{~m}^{-1}\right)\end{array}$ & $\begin{array}{r}\text { RADIUS } \\
(\mathrm{km})\end{array}$ & $\begin{array}{r}\text { SPEED } \\
\left(\mathrm{km} \mathrm{h}^{-1}\right)\end{array}$ & $\begin{array}{r}\text { REL HUM } \\
\text { (in \%) }\end{array}$ \\
\hline LARNACA & $\mathbf{3 . 2 2}$ & $\mathbf{2 . 6 0}$ & $\mathbf{0 . 2 4}$ & 16.24 & $\mathbf{- 7 . 0 7}$ & -0.38 \\
POLIS & $\mathbf{4 . 2 7}$ & $\mathbf{4 . 1 8}$ & $\mathbf{0 . 3 8}$ & $\mathbf{9 5 . 1 7}$ & -6.79 & -0.59 \\
MARSEILLE & -3.30 & 0.49 & $\mathbf{- 0 . 3 9}$ & 98.42 & -9.90 & -0.05 \\
CORFU & $\mathbf{4 . 7 8}$ & $\mathbf{1 . 0 4}$ & $\mathbf{0 . 2 1}$ & -0.82 & $\mathbf{- 9 . 3 1}$ & 1.61 \\
HERAKLION & $\mathbf{2 . 7 7}$ & $\mathbf{1 . 8 8}$ & $\mathbf{0 . 4 1}$ & 35.34 & $\mathbf{- 3 . 2 4}$ & 0.04 \\
METHONI & $\mathbf{9 . 6 0}$ & $\mathbf{4 . 2 2}$ & $\mathbf{0 . 6 3}$ & $\mathbf{1 7 0 . 5 3}$ & $\mathbf{- 5 . 0 3}$ & 0.91 \\
TEL AVIV & $\mathbf{6 . 4 6}$ & $\mathbf{3 . 6 3}$ & $\mathbf{0 . 6 0}$ & $\mathbf{2 4 3 . 8 5}$ & $\mathbf{- 9 . 4 9}$ & 0.08 \\
GENOVA & $\mathbf{2 . 5 5}$ & $\mathbf{6 . 4 0}$ & $\mathbf{0 . 2 5}$ & $\mathbf{2 4 3 . 1 1}$ & $\mathbf{- 6 . 9 7}$ & 1.34 \\
BRINDISI & $\mathbf{1 1 . 8 7}$ & $\mathbf{4 . 2 2}$ & $\mathbf{0 . 9 9}$ & $\mathbf{1 2 8 . 2 8}$ & $\mathbf{- 8 . 6 7}$ & -2.38 \\
CAGLIARI & -2.66 & 2.12 & -0.06 & 80.83 & -5.14 & $\mathbf{1 . 5 6}$ \\
MALAGA & $\mathbf{3 . 1 9}$ & $\mathbf{7 . 5 3}$ & $\mathbf{0 . 4 0}$ & $\mathbf{3 9 6 . 2 0}$ & -13.01 & -1.27 \\
ALGER & -1.41 & 0.16 & 0.15 & 40.40 & -6.71 & 0.63 \\
ALICANTE & -4.59 & -1.53 & $\mathbf{0 . 3 9}$ & 1.84 & -10.34 & $\mathbf{- 3 . 2 5}$ \\
BARCELONA & -2.74 & $\mathbf{0 . 5 1}$ & 0.14 & $\mathbf{1 3 6 . 5 9}$ & $\mathbf{- 1 5 . 9 7}$ & 0.10 \\
RIJEKA & 0.14 & $\mathbf{1 . 8 6}$ & 0.09 & 83.02 & -0.97 & $\mathbf{- 1 . 6 9}$ \\
\hline
\end{tabular}

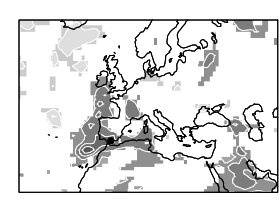

(a) MALAGA

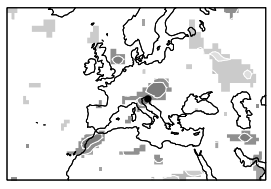

(d) RIJEKA

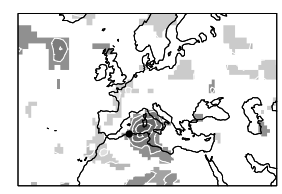

(g) ALGER

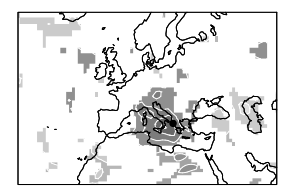

(j) $\mathrm{CORFU}$

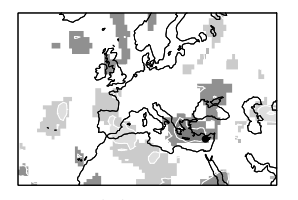

(m) POLIS

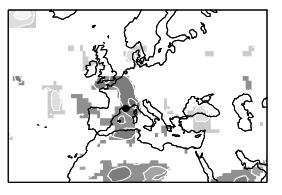

(b) MARSEILLE

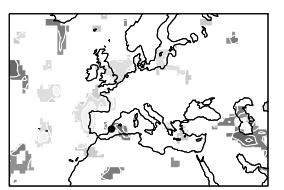

(e) ALICANTE

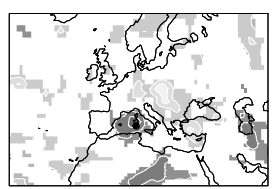

(h) CAGLIARI

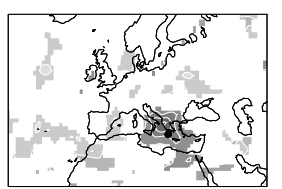

(k) METHONI

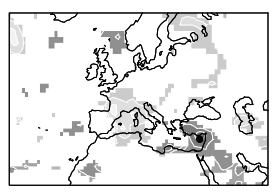

(n) LARNACA

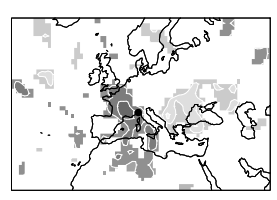

(c) GENOVA

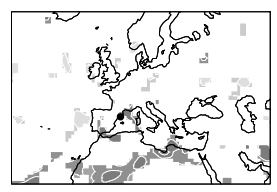

(f) BARCELONA

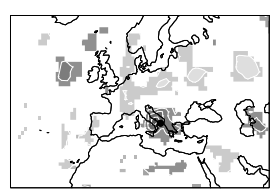

(i) BRINDISI

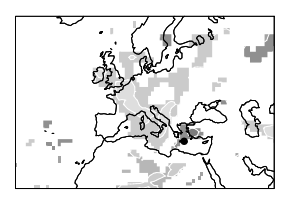

(1) HERAKLION

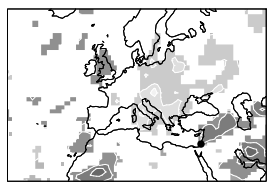

(o) TEL AVIV

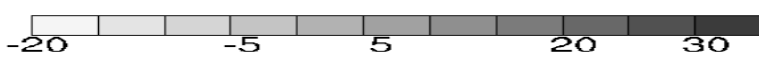

Fig. 19. Same as Fig. 17 except it shows the difference between composites of HUMR (relative humidity, \%). standard deviation and are plotted only when the difference is statistically significant at the $90 \%$ level (the Mann-Whitney test is used). Figure 21 is drawn with the same procedure, but considers depth and speed; Fig. 22 considers Laplacian and mean relative humidity.

Figure 20 shows that $\mathrm{C}_{90+98}$ cyclones have a larger radius and a stronger gradient than $\mathrm{C}_{25}$ cyclones. For 7 cases both the differences in extension and gradient are statistically significant. Figure 21 shows that $\mathrm{C}_{90+98}$ cyclones are slower (in many cases significantly) and in the most cases deeper (in most cases significantly) than $\mathrm{C}_{25}$ cyclones. These characteristics are stronger in the eastern than in the western Mediterranean. The dipole structure shown in Fig. 17 is compatible with the presence of a high-pressure system that reduces the speed of the cyclone. Figure 22 shows that $\mathrm{C}_{90+98}$ cyclones have mostly higher values of the Laplacian in the western Mediterranean and of relative humidity in the eastern Mediterranean. At the same time, the values of the Laplacian and humidity do not seem important in the eastern and western Mediterranean, respectively.

\section{Conclusions}

This study has analyzed the association between cyclones and winter (December-January-February) precipitation at 15 Mediterranean coastal locations. For each selected location, a list of precipitation events has been produced and their intensity $q$ percentile thresholds $\mathrm{Th}_{q}$ have been derived. Four values of $q$ have been considered corresponding to the 25,50 , 90 and 98 percentiles. The values obtained and the number of events above these thresholds exhibit a large variability across the MR due to the variability of precipitation regime at regional scale in the Mediterranean and also to incompleteness of the time series. 

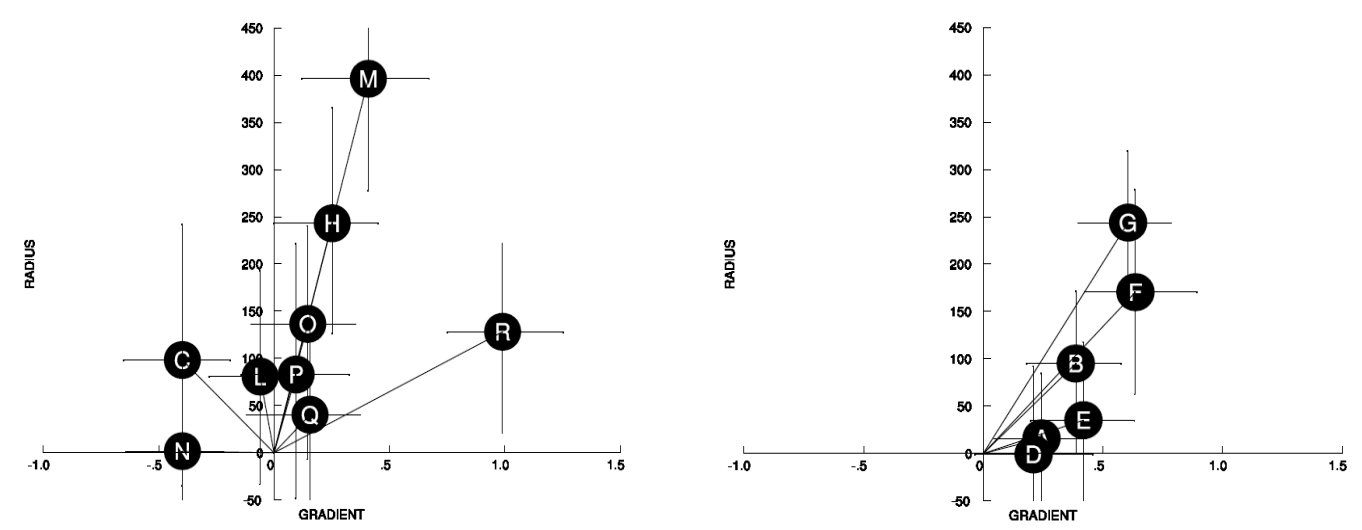

Fig. 20. Difference between gradient (in $\left.\mathrm{Pa} \mathrm{m}^{-1}\right) \times 10^{-3}$ and radius $(\mathrm{km})$ of $\mathrm{C}_{90+98}$ with respect to $\mathrm{C}_{25}$ in WM (left panel) and $\mathrm{EM}$ (right panel).
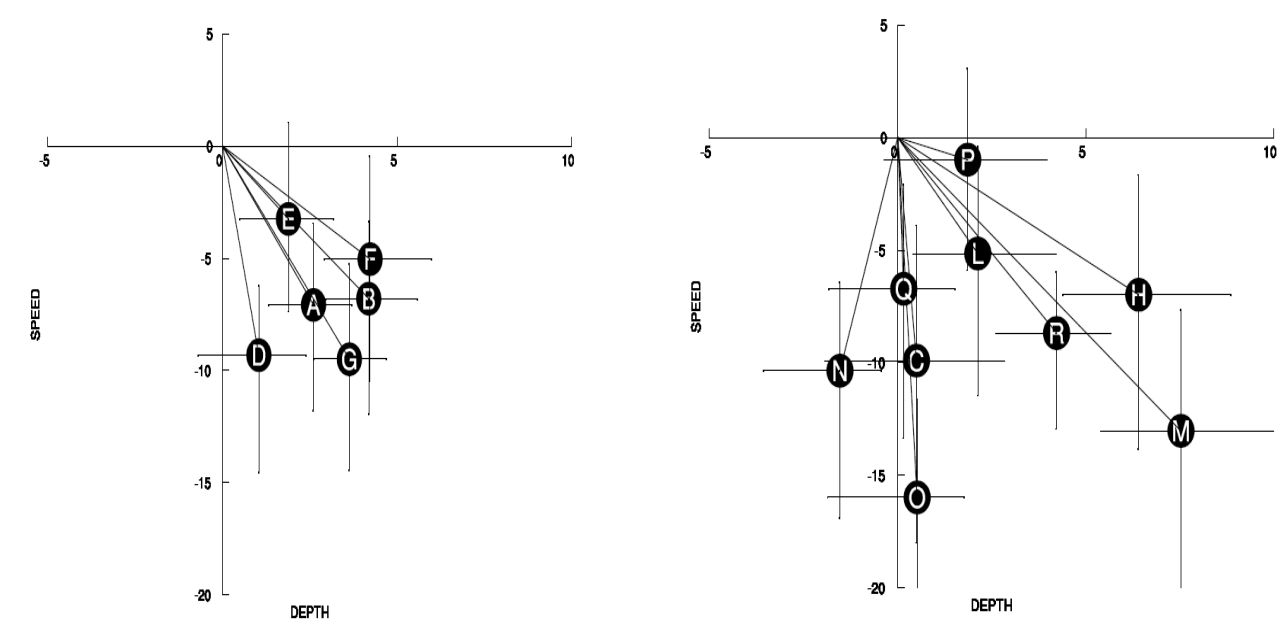

Fig. 21. Same as Fig. 20 except it shows difference between mean speed $\left(\mathrm{km} \mathrm{h}^{-1}\right)$ and depth $(\mathrm{hPa})$.

A significant negative tendency of winter total cumulated precipitation has been detected only in Larnaca, Polis, Cagliari and Corfu. All other stations show no significant trend. Considering four categories of events $\left(\mathrm{N}_{25}, \mathrm{~N}_{50}, \mathrm{~N}_{90}\right.$ and $\mathrm{N}_{98}$ ), a significant negative tendency in $\mathrm{N}_{50}$ has been observed in most locations. No significant tendency has been observed for others categories. However, though trends are not significant in all locations, all significant trends of $\mathrm{N}_{50}$ and of total precipitation (except at one station) are negative. Therefore, in spite of large spatial and time variability, these results support that precipitation along the coast of the Mediterranean Sea has decreased in the second half of the 20th century, but provide no evidence of changes in the number of severe and intense precipitation events.

The occurrence of precipitation events, in all but the most severe category, has been found to be linked to the negative phase of NAO and EAWR pattern, with NAO playing the main role in the western Mediterranean and EAWR in the central part. Also, the influence of the negative/positive phase of EA and negative phase of SCAN has been detected, though their importance is smaller than that of NAO and EAWR. The occurrence of intense events (in the $\mathrm{C}_{98}$ Category) is not associated with any large-scale monthly NHTP.

The study has confirmed the link between the cyclone activity and precipitation. In general, the probability of detecting a cyclone within a distance of $20^{\circ}$ from each station increases with the intensity of the precipitation event and decreases with the duration of a dry period. Cyclones producing intense precipitation events exhibit different characteristics in different areas of the Mediterranean region. In the northwestern areas, systems are either of Atlantic origin or secondary cyclones associated with the passage of major cyclones north of the Mediterranean Basin. In the eastern areas, cyclones producing intense precipitation are mostly generated inside the basin itself. In addition, an important fraction of severe precipitation events in the southern areas are produced by cyclones that are generated over northern Africa. The position of cyclone and the analysis of atmospheric 

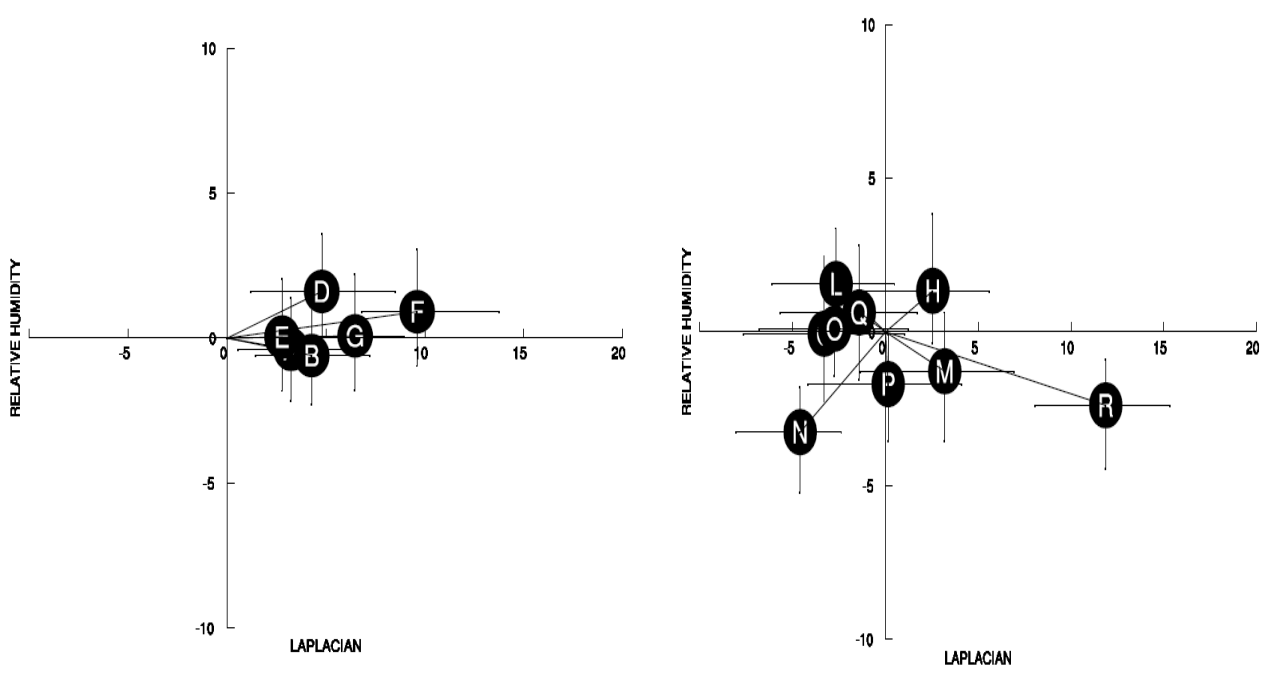

Fig. 22. Same as Fig. 20 except it shows differences in the Laplacian $\left(\mathrm{Pa} \mathrm{m}^{-1}\right) \times 10^{-10}$ and relative humidity.

patterns (SLP and Z500) associated with these events show that their spatial features produce an anomaly moisture flow favoring intense and prolonged precipitations.

Cyclones originated over North Atlantic and affecting WM are characterized by longer tracks and lifetime than the others. They either move along the mid latitude storm track or enter the Mediterranean region following the direction from northwest to southeast. Those originated in the MR, mainly over northern Italy and the Gulf of Genova, move along the Mediterranean storm track down to Greece and Albania. Cyclones originated in EM mainly belong to the kind of Cyprus lows, with the shortest lifetime and track length among Mediterranean cyclones.

The analysis of difference in Z500 and SLP spatial patterns associated with severe and mild precipitation events shows the importance of synoptic conditions favoring moisture flow as shown in previous studies (e.g., Toreti al., 2010). In both EM and WM, results show that intensity of the circulation (depth of the cyclone, Laplacian, gradient and extension) and in some cases moisture content of the middle atmosphere play an important role in the characterization of $\mathrm{C}_{90+98}$ (cyclones producing severe precipitation events) with respect to $\mathrm{C}_{25}$ (cyclones producing mild precipitation events). Also, the speed of a cyclone center is an important characteristic explaining the severity of the precipitation event, though significant statistical evidence is not always present, as already shown by previous studies for Italy (Tartaglione et al., 2006) and the Alps (Frei and Shär, 2001). These links between synoptic patterns and precipitation represent a tool that can be applied to GCM results to associate changes of precipitation rainfall patterns to synoptic dynamics (Lionello and Giorgi, 2007) and to help diagnosing increases in hazardous intense precipitation events and drier conditions for the Mediterranean region.

\section{Appendix A}

For the analysis of cyclone activity, a tracking algorithm has been employed to identify low-pressure systems over the MR. The method (Lionello et al., 2002) is based on the search of pressure minima in the SLP gridded fields. The tracking algorithm identifies the location where each cyclone originates and follows the trajectory of its pressure minimum until it disappears. The procedure involves the partitioning of the SLP fields into depressions by the identification of sets of steepest descent paths leading to the same SLP minimum, which is a point where the SLP value is lower than the SLP at the 8 nearest grid points. All the points crossed by a path leading to the same minimum are assigned to the same depression. Small depressions whose central minimum is at a distance less than $n$ grid points from the boundary of a different and deeper depression are included in the latter $(n$ has to be adjusted according to the grid resolution, and for ERA40 resolution is equal to 3 ). At the end of this procedure every point in the grid has been attributed to a cyclone, so that the whole domain is divided in partitions, one for each cyclone center. The position of the SLP minimum is associated with the average position of all points in its partition with SLP not more than $3 \mathrm{hPa}$ higher than the actual minimum. The trajectory associated with each cyclones is obtained by joining the location of the same low-pressure center in successive maps. The final result of the procedure is a list of cyclones, with the position of their center and some variables, such as SLP minimum (in Pa), Laplacian (in $\mathrm{Pa} \mathrm{m}^{-2}$ ), gradient (in $\mathrm{Pa} \mathrm{m}^{-1}$ ), depth $(\mathrm{hPa}$ ), radius (in $\mathrm{km}$ ) and position of the maximum of vorticity along the track. In this study also speed of the cyclone center and relative humidity in the inner part of the cyclone have been computed. 
The depth $D$ represents an estimate of the difference $P_{o^{-}}$ $P_{\min }$ where $P_{o}$ is the "background" SLP value and $P_{\min }$ the pressure minimum. In this computation it is assumed that

$D=P_{o}-P_{\min }=1.2\left(P_{\min }-P_{\text {ave }}\right)$,

where $P_{\text {ave }}$ is the mean value of the pressure within a radius $\mathrm{R}$ around the cyclone central minimum. If a Gaussian shape for the SLP distribution with standard deviation equal to $R$ is assumed, the exact relation linking $P_{\min }-P_{\text {ave }}$ to $P_{o}-P_{\min }$ is

$(2 R)^{2} \pi\left(P_{o}-P_{\text {ave }}\right)=\left(P_{o}-P_{\min }\right) \pi\left(1-e^{-(2 R)^{2}}\right)$,

which after some algebra gives

$D=P_{o}-P_{\min }=\alpha\left(P_{\text {ave }}-P_{\min }\right), \alpha \sim 1.2$.

Laplacian and gradient of each cyclone (used in Sect. 4) are the maximum values of Laplacian and gradient within the partition attributed to the cyclone.

The radius $R_{\mathrm{cyc}}$ is meant to represent the mean radius of the storm. It is computed as

$R_{\mathrm{cyc}}=\sqrt{\sum r_{i}^{2} / N_{\mathrm{cyc}}}$

where $r_{i}^{n}$ represents the distance of the point $i$ from the center of the cyclone and $i$ runs from 1 to $N_{\text {cyc }}$, which is the total number of points within the partition associated with the cyclone. For a cyclone with a Gaussian shape, $R_{\text {cyc }}$ coincides with $R$.

The cyclone speed represents the average speed of the cyclone center in the $24 \mathrm{~h}$ before 12:00 UTC of the day with maximum precipitation.

Relative humidity of the cyclone is the average value of relative humidity in the same time window used for computing the speed and in a squared box centered over the location where precipitation has been recorded and with a size of 8 grid points.

Edited by: A. Mugnai

Reviewed by: two anonymous referees

\section{References}

Alpert, P., Ben-Gai, T., Baharad, A., Benjamini, Y., Yekutieli, D., Colacino, M., Diodato, L., Ramis, C., Homar, V., Romero, R., Michaelides, S., and Manes, A.: The paradoxical increase of Mediterranean extreme daily rainfall in spiteof decrease in total values, Geophys. Res. Lett., 29, 31-1-31-4, doi:10.1029/2001GL013554, 2002.

Alpert, P., Baldi, M., Ilani, R., Krichak, S., Price, C., Rodó, X., Saaroni, H., Ziv, B., Kishcha, P., Barkan, J., Mariotti, A., and Xoplaki, E.: Relations between climate variability in the Mediterranean region and the tropics: ENSO, South Asian and African monsoons, hurricanes and Saharan dust, in "Mediterranean Climate Variability", Elsevier, Amsterdam, 2006.
De Zolt, S., Lionello, P., Nuhu, A., and Tomasin, A.: The disastrous storm of 4 November 1966 on Italy, Nat. Hazards Earth Syst. Sci., 6, 861-879, doi:10.5194/nhess-6-861-2006, 2006.

Frei, C. and Schär, C.: Detection probability of trends in rare events. Theory and applications to heavy precipitation in the Alpine region, J. Climate, 14, 1568-1584, 2001.

Funatsu, B. M., Claud, C., and Chaboureau, J. P.: Comparison between the large-scale environments of moderate and intense precipitating systems in the Mediterranean region, Mon. Weather Rev., 137, 3933-3959, doi:10.1175/2009MWR2922.1, 2009.

Gibson, R., Kaålberg P., and Uppala, S.: The ECMWF re-analysis (ERA) project, ECMWF Newsl., 73, 7-17, 1996.

Haylock, M. R., Hofstra, N., Klein Tank, A. M. G., Klok, E. J., Jones, P. D., and New, M.: A European daily high-resolution gridded dataset of surface temperature and precipitation, J. Geophys. Res. Atmos., 113, D20119, doi:10.1029/2008JD010201, 2008.

Hoskins, B. J. and Hodges, K. I.: New perspectives on the Northern Hemisphere winter storm track, J. Atmos. Sci., 59, 1041-1061, 2002.

Hyndman, R. J. and Fan, Y.: Sample Quantiles in Statistical Packages, American Statistician (American Statistical Association), 50, 361-365, 1996.

Jansa, A., Genovés, A., and Garcia-Moya, J. A.: Western Mediterranean cyclones and heavy rain, Part 1: Numerical experiment concerning the Piedmont flood case, Met. Apps, 7, 323-333, doi:10.1017/S1350482700001663, 2000.

Jansà, A., Alpert, P., Buzzi, A., and Arbogast, P.: MEDEX, cyclones that produce high impact weather in the Mediterranean, available at: http://medex.inm.uib.es (last access: 3 June 2013), 2001a.

Jansa, A., Genovés, A., Picornell, M. A., Campins, J., Riosalido, R., and Carretero, O.: Western mediterranean cyclones and heavy rain, Part 2: statistical approach, Meteorol. Appl., 8, 43-56, doi:10.1017/S1350482701001049, 2001b.

Klein Tank, A. M. G., Wijngaard, J. B., Können, G. P., Böhm, R., Demaree, G., Gocheva, A., Mileta, M., Pashiardis, S., Hejkrlik, L., Kern-Hansen, C., Heino, R., Bessemoulin, P., MüllerWestermeier, G., Tzanakou, M., Szalai, S., Pálsdóttir, T., Fitzgerald, D., Rubin, S., Capaldo, M., Maugeri, M., Leitass, A., Bukantis, A., Aberfeld, R., van Engelen, A. F. V., Forland, E., Mietus, M., Coelho, F., Mares, C., Razuvaev, V., Nieplova, E., Cegnar, T., López, J. A., Dahlström, B., Moberg, A., Kirchhofer, W., Ceylan, A., Pachaliuk, O., Alexander, V. L., and Petrovic, P.: Daily dataset of 20th-century surface air temperature and precipitation series for the European Climate Assessment, Int. J. Climatol., 22, 1441-1453, 2002.

Krichak, S. O., Alpert, P., and Dayan, M.: Role of atmospheric processes associated with hurricane Olga in December 2001 flash floods in Israel, J. Hydrometeorol., 5, 1259-1270, 2004.

Lionello, P. and Giorgi, F.: Winter precipitation and cyclones in the Mediterranean region: future climate scenarios in a regional simulation, Adv. Geosci., 12, 153-158, doi:10.5194/adgeo-12-1532007, 2007.

Lionello, P., Dalan, F., and Elvini, E.: Cyclones in the Mediterranean region: the present and the doubled $\mathrm{CO}_{2}$ climate scenarios, Clim. Res., 22, 147-159, 2002.

Lionello, P., Malanotte-Rizzoli, P., Boscolo, R., Alpert, P., Artale, V., Li, L., Luterbacher, J., May, W., Trigo, R., Tsimplis, M., Ulbrich, U., and Xoplaki, E.: The Mediterranean Climate: An 
overview of the main characteristics and issues, in: Mediterranean Climate Variability, Elsevier, Amsterdam, 2006a.

Lionello, P., Bhend, J., Buzzi, A., Della-Marta, P. M., Krichak, S., Jansà, A., Maheras, P., Sanna, A., Trigo, I. F., and Trigo, R.: Cyclones in the Mediterranean region: climatology and effects on the environment, in: Mediterranean Climate Variability, Elsevier, Amsterdam, 2006b.

Maheras, P. and Anagnostopoulou, Ch.: Circulation types and their influence on the interannual variability and precipitation changes in Greece, Mediterranean climate-variability and trends, Springer Verlag, Berlin, Heidelberg, 2002.

Maheras, P., Tolika, K., Anagnostopoulou, Chr., Vafiadis, M., Patrikas, I., and Flocas, H.: On the relationships between circulation types and rainfall variability changes in Greece, Int. J. Climatol., 24, 1695-1712, 2004.

Mehta, A. V. and Yang, S.: Precipitation climatology over Mediterranean Basin from ten years of TRMM measurements, Adv. Geosci., 17, 87-91, doi:10.5194/adgeo-17-87-2008, 2008.

Moberg, A., Jones, P. D., Lister, D., Walther, A., Brunet, M., Jacobeit, J., Alexander, L. V., Della Marta, P., Luterbacher, J., Yiou, P., Chen, D., Klein Tank, A. M. G., Saladié, O., Sigrò, J., Aguilar, E., Alexandersson, H., Almarza, C., Auer, I., Barriendos, M., Begert, M., Bergstroem, H., Boehm, R., Butler, C. J., Caesar, J., Drebs, A., Founda, D., Gerstengarbe, F., Micela, G., Maugeri M., Oesterle H., Pandzic K., Petrakis M, Srnec L., Tolasz R., Tuomenvirta, H., Werner, P., Linderholm, H., Philipp, A., Wanner, H., and Xoplaki, E.: Indices for daily temperature and precipitation extremes in Europe analysed for the period 1901-2000, J. Geophys. Res., 111, 1-25, 2006.

Norrant, C. and Douguédroit, A. : Monthly and daily precipitation trends in the Mediterranean (1950-2000), Theor. Appl. Climatol., 83, 89-106, 2006.

Reiser, H. and Kutiel, H.: Rainfall uncertainty in the Mediterranean: Intra-seasonal rainfall distribution, Theor. Appl. Climatol., 100, 105-121, 2010.

Reiser, H. and Kutiel, H.: The dependence of the annual total on the number of rain spells and their yield in the Mediterranean, Geograf. Ann. Ser A, 94, 285-299, doi:10.1111/j.14680459.2011.00444.x, 2012.

Sen, P. K.: Estimates of the regression coefficient based on Kendall's tau, J. Am. Stat. Assoc., 63, 1379-1389, 1968.

Tartaglione, N., Speranza, A., Dalan, F., Nanni, T., Brunetti, M., and Maugeri, M.: The mobility of Atlantic baric depressions leading to intense precipitation over Italy: a preliminary statistical analysis, Nat. Hazards Earth Syst. Sci., 6, 451-458, doi: 10.5194/nhess-6-451-2006, 2006.

Theil, H.: A rank-invariant method of linear and polynomial regression analysis, Part 3., Proceedings of Koninalijke Nederlandse Akademie van Weinenschatpen A., 53, 1397-1412, 1950.
Toreti, A., Xoplaki, E., Maraun, D., Kuglitsch, F. G., Wanner, H., and Luterbacher, J.: Characterisation of extreme winter precipitation in Mediterranean coastal sites and associated anomalous atmospheric circulation patterns, Nat. Hazards Earth Syst. Sci., 10, 1037-1050, doi:10.5194/nhess-10-1037-2010, 2010.

Trigo, I. F., Davies, T. D., and Bigg, G. R.: Decline in Mediterranean rainfall caused by weakening of mediterranean cyclones, Geophys. Res. Lett., 27, 2913-2916, 2000.

Trigo, R., Xoplaki, E., Zorita, E., Luterbacher, J., Krichak, S., Alpert, P., Jacobeit, J., Saènz, J., Fernandez, J., GonzalezRouco, F., Garcia-Herrera, R., Rodo, X., Brunetti, M., Nanni, T., Maugeri, M., Türkeş, M., Gimeno, L., Ribera, P., Brunet, M., Trigo, I. F., Crepon, M., and Mariotti, M.: Relationship between variability in the Mediterranean region and mid-latitude variability, in: Mediterranean Climate Variability, Elsevier, Amsterdam, 2006.

Türkeş, M.: Influence of geopotential heights, cyclone frequency and southern oscillation on rainfall variations in Turkey, Int. J. Climatol., 18, 649-680, 1998.

Ulbrich, U., Lionello, P., Belušić, D., Jacobeit, J., Knippertz, P., Kuglitsch, F. G., Leckebusch, G. C., Luterbacher, J., Maugeri, M., Maheras, P., Nissen, K. M., Pavan, V., Pinto, J. G., Saaroni, H., Seubert, S., Toreti, A., Xoplaki, E., and Ziv, B.: Climate of the Mediterranean: Synoptic patterns, temperature, precipitation, winds and their extremes, in: The Climate of the Mediterranean Region, From the past to the future, Elsevier, Amsterdam, 2012.

Van den Besselaar, E. J. M., Haylock, M. R., van der Schrier, G. and Klein Tank, A. M. G.: A European Daily High-resolution Observational Gridded Data set of Sea Level Pressure, J. Geophys. Res., 116, D11110, doi:10.1029/2010JD015468, 2011.

Van Engelen, A., Klein Tank, A., Van der Schrier, G., and Klok, L.: European Climate Assessment \& Dataset (ECA\&D), Report 2008, "Towards an operational system for assessing observed changes in climate extremes", KNMI, De Bilt, The Netherlands, 68 pp., 2008.

Wallace, J. M., Lim, G., and Blackmon, M. L.: Relationship between cyclone tracks, anticyclone tracks and baroclinic waveguides, J. Atmos. Sci., 45, 439-462, 1988.

Xoplaki, E., Luterbacher, J., and González-Rouco, J. F.: Mediterranean summer temperature and winter precipitation, large-scale dynamics, trends, Il Nuovo Cimento, 29, 45-54, 2006.

Zhang, X., Aguilar, E., Sensoy, S., Melkonyan, H., Tagiyeva, U., Ahmed, N., Kutaladze, N., Rahimzadeh, F., Taghipour, A., Hantosh, T. H., Albert, P., Semawi, M., Karam, A. M., Al-Shabibi, M. H. S., Al-Oulan, Z., Zatari, T., Khelet, I. A. D., Hamoud, S., Sagir, R., Demircan, M., Eken, M., Adiguzel, M., Alexander, L., Peterson, T. C., and Wallis, T.: Trends in Middle East climate extreme indices from 1950 to 2003, J. Geophys. Res., 110, D22104, doi:10.1029/2005JD006181, 2005. 